\title{
COVID-19 Krizi, Telework ve Dijitalleşme: Çağrı Merkezi Çalışan Deneyimleri
}

\author{
Çiğdem ÇALAPKULU ${ }^{1}$, Seda YEMEN ${ }^{2}$ ve Esra DOĞAN ${ }^{3}$
}

$\ddot{\mathrm{O} z}$

2019 y1l itibari ile dünya gündemini meşgul eden Covid-19 pandemisi kurum ve kuruluşların iş yaşam faaliyetleri ve iş kültürleri üzerinde radikal değişikliklere yol açmıştır. Covid-19 krizi nedeni ile sosyal izolasyon sürecinin uygulanması ve birçok alanda kısıtlamaların getirilmesi şirketleri, süreçlerini yürütmek için belirli stratejiler uygulamaya yönlendirmiştir. Bu noktada son dönemlerde bilgi ve iletişim teknolojilerinin ve dijitalleşmenin iş ve istihdam kritikleri üzerindeki etki alanının gelişmesi vasıtasıyla dikkat çeken Telework (uzaktan çalışma) sisteminin şirketler için önemli bir alternatif olduğu gözlemlenmiştir. Salgının yayılım hızını ve etkisini en aza indirmek için alınan tedbirler kapsamında dünyanın dört bir yanında çalışanlar sosyal mesafeli çalışmaya olanak veren tele çalışma sistemine geçirilmiş ve dijitalleşen yeni bir yapılanma içerisine girmiştir. Bu bilgiler ışığında sektörel bazlı değerlendirmeler yapıldığında çağrı merkezlerinin bu sürece en çok adapte olan iş kolu olduğu belirlenmiştir. O nedenledir ki araştırma ekseni çağrı merkezi çalışanları üzerinde yoğunlaştırılmıştır. Nicel araştırma yöntemlerinden betimsel araştırma modelinin kullanıldığı bu çalışmada, Twitter aracilığ1 ile random örneklem alınarak aktif çalışma yaş skalasına giren 25-30 yaş arası 300 çağrı merkezi işgörenine anket uygulanmış, çalışanların telework algıları hakkında bilgi edinmek, sürecin iletişimsel boyutunu incelemek ve dijitalleşmenin etkilerini görmek amaçlanmıştır. Bu araştırma, Covid-19 krizi nedeni ile iş yaşamına giren telework sisteminin dijitalleşme hâkimiyeti ile pandemi sonrasında da iş kültürünün önemli bir parçası olacağı ileri sürülmektedir.

Anahtar Kelimeler: Tele Çalışma, Covid-19, Dijitalleşme, Çağnı Merkezi, Pandemi

\section{COVID-19 Crisis, Telework and Digitalization: Call Center Employee Experiences}

\section{Abstract}

As of 2019, the Covid-19 pandemic, which occupied the world agenda, has led to radical changes on the business life activities and business cultures of institutions and organizations. Due to the Covid-19 crisis, the implementation of the social isolation process and the imposition of restrictions in many areas have led companies to implement certain strategies to carry out their processes. At this point, it has been observed that the Telework system, which has attracted attention with the development of the impact area of information and communication technologies and digitalization of business and employment criteria, is an important alternative for companies. Within the scope of the measures taken to minimize the spreading speed and impact of the epidemic, employees all over the world have been switched to a telework system that allows social distant work and introduced a digitalized new structure. In the light of this information, when sectorbased evaluations are made, it has been determined that call centers are the business line that adapts most to this process. That is why the research axis has been focused on call center employees. In this study, in which the descriptive research model was used, one of the quantitative research methods, a random sample was taken via Twitter and a survey was conducted between 300 call center employees between the ages of 25-30 who were in the active working age scale, it was aimed to learn about the telework perceptions of the employees, to examine the communicative dimension of the process and to see the effects of digitalization. This research suggests that the telework system, which entered the business life due to the Covid-19 crisis, will be an important part of the business culture after the pandemic with dominant digitalization.

Key Words: Telework, Covid-19, Digitalization, Call Center, Pandemic

\section{Atıf İçin / Please Cite As:}

Çalapkulu, Ç., Yemen, S. ve Doğan, E. (2021). COVID-19 krizi, telework ve dijitalleşme: Çağn1 merkezi çalışan deneyimleri. Manas Sosyal Araştırmalar Dergisi, 10(4), 2402-2422.

\footnotetext{
${ }^{1}$ Dr. Öğr. Üyesi - Sakarya Üniversitesi İletişim Fakültesi, ccalapkulu@sakarya.edu.tr

ORCID: 0000-0002-3423-0440

2 Yüksek Lisans Öğrencisi - Sakarya Üniversitesi Sosyal Bilimler Enstitüsü, yemenseda01@gmail.com

D ORCID: 0000-0001-9821-4557

3 Yüksek Lisans Öğrencisi - Sakarya Üniversitesi Sosyal Bilimler Enstitüsü, doganesraa20@gmail.com

(iD) ORCID: 0000-0003-3022-7954
} 


\section{Giriş}

2019 yllı son demlerinde ortaya çıkarak tüm dünyayı etkisi altına alan yeni tip COVID-19 virüsü ilk olarak Çin'in Wuhan kentinde kendini göstermiş, Dünya Sağlık Örgütünce uluslararası halk sağlığı acil durumu olarak ilan edilen bu salgına ülkemizde de Mart 2020'de rastlanmışır. Tüm dünya ekseninde ve ülke sınırları içerisinde hastalı̆̆ın yayılım hızını önlemek amacıyla pek çok tedbir alınmış ve pandemi sürecine girilmiştir. COVID-19 salgınının yayllım ve bulaşım riskini en aza indirgemek adına sosyal izolasyon ile birlikte insanların birbiri ile olan bağlantısını en aza düşürmek için sosyal mesafe koşulu getirilmiştir. Bu iki kural hayati önem taşımaktadır. Salgının fiziksel, zihinsel ya da tinsel hükmünün dışında ölümcül etkisinin de yüksek oranda olması, insanların yaşam alanlarını ve çalışma formlarını büyük ölçüde değiştirmiştir. Bu sürece yönelik atılan bazı adımlar; eğitimin online/uzaktan eğitim modeline geçirilerek uygulamaya koyulması, ülke giriş- çıkışlarının belirli bir süre ile kapatılması, sokağa çıkma yasaklarının ve sınırlamalarının getirilmesi, seyahat kısıtlamalarının gerçekleştirilmesi ve başta alt yapısı uygun olan şirketler olmak üzere esnek/ dönüşümlü çalışma sistemine geçilmesidir. Pandemi ile birlikte bazı şirketler sosyal mesafe ve izolasyon şartlarına uyum sağlamak için işgören sayılarını azaltmaya ya da işyerlerini geçici süreyle kapatmaya giderken bazı şirketler ise ekonomik faaliyetlerini sürdürebilmek ve işgören sağlık / güvenliğini korumak için farklı yollara başvurarak telework (uzaktan çalışma) sistemine yönelmiştir.

Telework sistemi, uzaktan çalışma, sanal ofis, esnek çalışma, bilgi ağı oluşturma gibi farklı kavramlarla literatürde yer almaktadır. Tartışmalı bir tema olarak çalışmalara konu olsa da COVID-19 ile birlikte yeni bir iş modeli olarak karşımıza çıkmaktadır. Bilhassa bilgi iletişim teknolojilerinin hızla gelişimi ve dijitalleşmenin etkisiyle tele çalışma modeline rağbet artarken özel sektör alanlarında ve kamu işyerlerinde telework çalışma yöntemlerinin benimsendiği gözlemlenmiştir. İletissim teknolojilerinin ve enformasyonun gelişimine bağlı olarak bireylerin işyerlerine gitmeden işlerini kendi özerk alanlanında yapabilecekleri ve çalışma şekillerini değiştirebilecekleri anlamına gelmekte ve bu sistemin farklı bir formu, Alvin Toffler'in "Üçüncü Dalga" isimli kitabında elektronik köşk kavramı ile açıklanmaktadır. Salgına yönelik her yeni bir dalganın oluşması, yaşam standartlarında, eğitim düzeylerinde ve çalışma koşullarındaki değişim, bu tanımlamanın gerçekleşmeye başladığının bir göstergesi olmaktadır. Dijital dünyanın ve yapay zeka teknolojilerinin entegre edildiği bu dönem telework sisteminde çalışanların hayatını zorlaştırmaktan öteye niteliklerini değiştirmeye ve geliştirmeye firsat tanımaktadır. Telework sisteminde çalışanların yaşam tarzlarını dijitalleşmeye dönüştürerek hem verimlilik hem de performanslarının artırılmasını sağlamak, dijitalleşme sürecinde başarılı olma konusunda büyük önem taşımaktadır (Ersöz ve Özmen, 2020, s. 178).

COVID-19 krizi ile önemli sayıda çalışan uzaktan çalışma (telework) sistemine geçmiş ve yeni bir yapılanma içerisine girmiştir. Bu araştırmanın amacı; çalışanların tele çalışma algıları hakkında bilgi edinmek, dijitalleşmeyi deneyimleyen işgörenlerin çalışma hayatlarındaki iş- yaşam balansını gözlemlemek ve iletişimsel boyutunu incelemektir. Bu çalışma ile Türkiye'de telework çalışma sistemi ne ifade etmektedir, çağrı merkezi çalışanlarının telework'e ilişsin tutumları nelerdir, COVID-19 krizinde telework yöntemine geçilmesinin topluma ve toplumsal alana olumlu ve olumsuz yönleri nelerdir? gibi sorulara yanıt aranmaktadır. Bu araştırmada temel olarak telework çalşşma sisteminin genel çerçevesinin belirlenmesi, COVID-19 krizi sonrasında dahi telework çalışma prensibinin yeni çalışma biçimi olarak iş yaşantısına yerleşeceği ve hukuki düzenlemeler ile dijitalleşmenin hayatımızda önemli roller oynayacağı ileri sürülmektedir.

\section{Telework Sistemi ve Türleri}

“Tele” sözcüğü Yunanca'dan evrilmiş bir ön ek olmakla birlikte "uzaktan” anlamına gelmektedir. Buna göre "tele" ve "work" kombinasyonu Türkçe tabiri ile "uzaktan çalışma" olarak tercüme edilmektedir. Telework bir çalışmanın yapilış formudur. İşveren denetiminin az olduğu, kurumların kapsam alanı dışında yürütülen, bilgi ve iletişim teknolojileri vasıtası ile işletmeyle irtibat kurulan, çalısan tarafinda iş yeri bağımlılığını aza indirgeyen esnek bir çalışma sistemidir (Yavuz, 1995, s. 64). Tradinasyonel iş anlayışının dışına çıkan bu sistem, çalışan bireylere belirlenmiş zaman kurallarının ötesine geçerek alternatif bir alan yaratmakta, yöneten ve yönetilen arasında mutabık kalınan bir anlaşmaya dayanmaktadır.

Telework, kapsamlı bir çerçeveye sahip olduğu için genel geçer tek bir tanımlaması yoktur. Bu noktada farklı açıklama biçimlerine sahip olan birçok terimin varlı̆̆ı bilinmektedir. Yazınlara bakıldığında; tele haberleşme (telecommuting), evden çalışma (homeworking), sanal ofis/işyeri (virtual office), uzaktan çalş̧ma (remote working), esnek çalışma (flexible working), bilgisayar ağı oluşturma (networking), siber 
çalışma (cyberwork) gibi terimler telework yerine kullanılan farklı seçeneklerdir. Farklı ifadeler bulunsa da telework tanımlamalarında hemfikir olunan üç temel kavram olduğu görülmektedir. Bunlar; organizasyon, mekan ve teknolojidir (Ölçer, 2004, s. 146). Uzaktan çalışma ve bilgi teknolojileri organizasyonel değişimi beraberinde getirmektedir. Bilgi ve iletişim teknolojilerinin getirileri ile çalışanı işe getirmek yerine işi çalışana götürme esasına dayalı olan, işyeri merkezinden ayrı, çalışanı farklı mekân ve alana odaklayan, iş yaşam dengelerini değiştiren alternatif bir yapılanma olarak aktarılabilmektedir. Sanayi toplumundan bilgi toplumuna geçişle birlikte, bilişim teknolojilerinde yaşanan hızlı evrilmeler iş kritiklerini ve geleneksel iş organizasyonlarını dönüştürmesi sonucunda ortaya çıkan, işin en azından belirli bir kısmının işin merkez ofislerinden veya üretim imkânlarından uzak bir yerde, bilgi ve iletişim teknolojileri aracillğıyla yerine getirildiği bir çalışsma şeklini ifade etmek için kullanılmaktadır.

Zamane iş yapılanmasındaki tadillerin esas hususiyetlerinden bir tanesi de, mekân ve faaliyet alanı esnekliğidir. Bu elastike yapı, çalışan için iş stresinin düşmesine, verimlilikte randıman alınmasına, iş- yaşam dengesinin yumuşatılmasına, yaratım gücünün ve iş bağımsızlığının artırılmasına olanak tanıyarak hem işverene hem de işgörene büyük kazanım firsatı oluşturmaktadır.

Telework bir bakıma örgütsel maliyeti indirgemeyi hedeflese de iş- yaşam balansını tehsil etmek ve iş baskısını düşürmek için daha çok uygulama alanı bulmaktadır. Bu açıdan bakıldığında telework, işgörenlerin aile ilişkilerini sağlamlaştırmakta, zaman idaresini optimize etmekte, ev-aile sorumluluklarını yerine getirmeye olanak tanıyarak iş- yaşam görevlerini dengeleme esnekliği sunmaktadır (Görmüş, 2020, s. 487). $\mathrm{Bu}$ aktarımların aksine karşıtlam olarak telework, iş-yaşam istikrarsızlı̆ııın bir sebebi de olabilmektedir. Ev esaslı çalışma yürütmek, iş gücü ve şahsi alan çizgisindeki iletkenliği artırarak, mental ve fiziksel olarak stres düzeyini yükseltebilmekte, iş bitirim süresinde çalışan için engel teşkil edebilmektedir (Morganson, Major, Oborn, Verive ve Heelan, 2010, s. 580). Ve dahi iş- yaşam ortamında çarpışmaya neden olma, uzun mesai saatlerine sebebiyet verme, iş yükünün bitmeme eğilimi göstermesi gibi yitirimleri de bulunmaktadır. Farklı noktalardan değerlendirildiğinde kimileri için iş-yaşam dengesini sağladığ1 düşünülüyorken, kimileri için ise bu dengenin olumsuz etkilendiği düşünülmektedir.

Çalışanların iş alanları öngörülerek telework türleri şu şekilde sınıflandırılmıştır.

- Ev esasli

- Tele merkez esaslı

- Hareketli / Mobil esasli

\section{Ev Esaslı Çalışma}

Ev esaslı çalışma sistemi; çalışanların iletişim teknolojilerine vakıf olarak kurumun santra alanına uzaktan bağlantı kurduğu ve çalışanın kendi yaşam sahasında düzenli ödeme alarak iş temposunu sürdürdüğü bir faaliyet biçimidir. Geleneksel evden çalışma kalıbının dışına çıkan ev esaslı telework, yeni iletişim teknolojilerini kullanmaya dayanan, güçlü vasıf gerektiren, merkezinde profesyonelliği barındıran iş bölümleri için olası görülmektedir. Hizmet sektöründeki arz- talep oranının yükselmesi ve iletişim alanının önlenemez gelişimi ile ev esaslı çalışma sisteminin iş sektöründe yeni bir alan oluşturduğu söylenmektedir.

Ev esaslı telework, çalışma süresi esnekliği ile birlikte mekân esnekliğini de içine alan geniş bir faaliyet sistemidir. Bu sistem aynı zamanda ev dışında çalışma olanağı var olmayan ya da tercih etmeyen bireyler için önemli bir gelir kapısı olabilmekte ve bireylerin istihdam edilerek işgücüne karışmalarını sağlayabilmektedir. Öte yandan işgören, evden çalışma yürütürken bir veya birden fazla işveren aracilığıyla iş yapılabilmekte ya da freelance, bireysel çalışma gerçekleştirilebilmektedir.

İsgörenlerin ev esaslı telework biçimine odaklanması ve tercih etmesindeki en mühim hususlar, iş aile kalıplarındaki esneklik, ulaşım problemlerinin ortadan kalkması, bağımsızlık eğilimi, alternatif faaliyet opsiyonlarıdır (Burch, 1991). Ayrıca gürültü gibi olumsuz faktörlerin üst seviyede olduğu ofis ortamı yerine bildikleri düzen çerçevesinde çalışmak, iş verimliliğinin artmasına ve çalışanın diğer bireyler tarafindan çalışma alanı ihlaline maruz kalmamasına imkân vermektedir.

Ev esaslı çalışma örneğinin avantajlarının yanında dezavantajları olduğu gerekçesi ile eleştirilere neden olan bazı tarafları bulunmaktadır. Bunlar; işgörenin sosyal haklar hususunda geri planda kalması, kanuni belirsizlikler, izolasyon düzeyinin yükselmesi, ilişkinlik hissinin düşmesi veya yok olması, iş-yaşam dengesinin bozulmasıdır. 


\section{Tele Merkez Esaslı Çalışma}

Tele merkez esaslı çalışma biçimi; temel hizmet alanından ve şirket ana kaynaklarından uzakta, bilgi ve iletişim teknolojileri ile tasarlanmış özel merkezlerden çalışmanın yürütülmesidir. Bu çalışma alanları işyerinden çalışma yürütmek ve ev esaslı çalışma arasında mühim bir uzlaşma aracı olarak görülmektedir. Fiziksel olarak aynı yerde yoğunlaşmış işgörenleri kapsayan bir telework türüdür (Tan, 2007, s. 47).

Tele köyler olarak da adlandırılan bu merkezler, toplumsal izolasyonu önlemek, iş gidiş geliş zamanı hususunda tutum sağlamak, uzak ana ofisleri yakın kilmak gibi avantajlara sahiptir (Meşhur, 2007, s. 266). Tele köyler olarak bilinirliğinin temel sebebi, eski dönemlerde il merkezlerinin kapsam alanı dışında bilhassa köylerde bu alanların oluşturulmasından gelmektedir. Daha çok Avrupa'da köy, kırsal alan merkezileştirmesi yapılmıştır. Bu telework biçimi dünyanın farklı bölgelerinde türlü sektörel amaçlarla kurulmuştur. Tele merkez esaslı çalışmanın ilk örnekleri, Almanya, Brezilya, İspanya, İngiltere, İskoçya, İrlanda, Fransa ve İskandinav ülkelerinden bazılarıdır (İnceacar, 2019, s. 842).

Tele merkez esaslı çalışma sisteminin yönetim tarafindan tercih edilmesinin başlıca nedenleri, işgörenlere karşı güven duygusunun tam oluşmaması, iş aksama ihtimalinin düşünülmesi, her hanede yeterli teknolojik donanımın bulunmaması ve her haneye gerekli ekipmanı sunma firsatlarının olmamasından kaynaklanmaktadır. Tele merkez sistemine işgörenlerin rağbet göstermesinin en önemli nedenleri ise, iş yapış stilleri gereğince evden çalışmaya uygun olmamaları, evden çalışmaya imkân verecek ekipmana sahip olmamaları, organizasyonel yapıya eğilim göstermeleri ve tele merkeze yakın, uygun lokasyonda ikamet etmeleridir.

\section{Hareketli / Mobil Esasılı Çalışma}

Mobil esaslı çalışma sisteminde ev esaslı ya da tele merkez esaslı çalışma yürüten çalışanlarda olduğu gibi belirli, sabit bir alan mevcut değildir. Seyahat etmeyi ya da sürekli hareket halinde olmayı gerekli kılan herhangi bir iş kolu aracılı̆̆gyla çalışanların, merkez ofisle teknolojik iletişim donanımlarının (e-mail, data ölçeklerine ulaşım, telekomünikasyon vs.) aktif kullanılması sonucu temasa geçmesi ile yürütülmektedir.

Mobil esaslı telework sisteminde çalışanlar her noktayı iş yerine dönüştürebilmektedir. Ev, müşteri iş yeri, uçak, otel, kafe gibi birçok alandan firma ile teknoloji yardımıyla iletişimsel bağlantı kurulabilmektedir. Bu yapı, mobil işgörenler için kabiliyetlerini yönetime ya da tüketiciye birebir sunma firsatı oluşturmakta, müşteri portföyüne daha kaliteli işlev sunulmasını sağlamakta ve iş yaşam dengesini kendilerinin belirlemesine olanak tanımaktadır.

\section{Covid-19 Krizi ve Telework}

Var olduğu süre boyunca pek çok felaketle karşı karşıya gelen insanoğlunun, yaşam standartlarını sürdürebilmek için her bir yıkım riskinde farklı yollara başvurarak önlem almaya gayret gösterdiği bilinmektedir. Günümüz dünyasını da işgal eden bu yıkımlardan bir tanesi olan salgınlar, insan hayatına etki ettiği her dönemde sosyal, toplumsal, ekonomik düzen üzerinde büyük etkilere yol açarak hayati değişimlere neden olmaktadır.

Asri dünyanın "İspanyol Gribi (1918-1920)" sonrasında gördüğü en büyük sağlık problemi olan "COVID-19 (Corona Virüs)” salgını, 2019 yılı aralık ayında Çin'de patlak vermiş ve ciddi sonuçları ile kısa bir süre içerisinde tüm dünyayı ekseni altına almıștır. Ciddi sıhhat problemleri oluşturması ve ölüm oranlarının yüksek olması nedeniyle küresel bir krize dönüşmüştür. Durumun vehameti neticesinde Dünya Sağlık Örgütü tarafindan "pandemi” ilan edilirken, Mart 2020'de Türkiye'de ilk vaka tespit edilmiş ve salgının ülkemizde etkili olmaya başladığı bildirilmiştir.

Yargitay kararlarına göre; sel, kar, deprem gibi doğal olaylar nedeniyle ulaşımın kesilmesi, salgın hastalık sebebiyle karantina uygulaması gibi durumlar 4857 sayllı İş Kanunu kapsamında mücbir nedenler arasında sayılmaktadır (Telli, 2020). COVID-19'un hizla yayılmasının önlenmesi kapsamında; eğitim süreçlerine ara verilerek uzaktan eğitim modeline geçilmesi, ülke giriş çıkışlarınınsınırlarının kapatılması, esnek, mesafeli ya da dönüşümlü çalışma sisteminin onaylanması, belirli yasakların getirilmesi (sokağa çıkmak, düğün- eğlence organizasyonların iptali vs.), sosyal izolasyonun kurulması, karantina yürütümleri yaşam standardizasyonunu kısıtlayarak önemli varyasyonların oluşmasına zemin hazırladığ1 görülmektedir.

COVID-19 krizi süresince siyasetçiler, sağlıkçılar, alanında bilir kişi olanlar, insan yaşam dengesine zarar vermeden korunmanın farklı usüllerini aramaktadır. Hastalı̆ın yayılım etkisini azaltmak için alınan 
önlemler, iktisadi çalışmalardaki küçülmeler, eğitim, iş yaşantısındaki tahavvüller, yaşantısal değerleri zora sokmakta, insanın içtimai, zihinsel, mali, tinsel ve şahsi varlıklarını etki alanına almaktadır (Alpago ve Alpago, 2020, s. 101). Ferdi ve toplumsal sürekliliğin elde edilmesi için nice yenilik süratli bir biçimde yeni normale uyarlanmaktadır. Bunlardan en dikkat çekenleri; eğitim alanında online bir düzen kurulması ve iş alanında mesafeli çalışma sistemlerinin oturtulmasıdır. Bu açıdan bakıldığında önceki dönemlerde sınırlı zaman dilimlerinde kullanılan telework sisteminin uzun dönemli kullanıma evriltildiği görülmektedir. ILO (International Labour Organization) tarafindan belirtilene göre telework farklı türleri ile sınırlı bir kitle tarafindan belirli periyotlarda geçici kullanımı olan bir sistem olduğu söylenebilecekken, virüsün yayılma tehlikesini indirgemek için pek çok sektörün telework sistemine uygun iş kollarını uzun süreli, sanal çalışmaya geçirmesi gerekmektedir (akt. Görmüş, 2020, s. 488). Bu bilgiler 1şında telework sisteminin düzgün bir planlama ile tatbik edilebilmesi pandemi mücadelesinde değerli bir güç olacağını göstermektedir.

Telework çalışma sistemleri, hem kurum ve kuruluşların iktisadi hareketliliğini dinamik tutmakta hem işgörenlerin sıhhat ve emniyetini güven altına almakta hem de yayılım kapasitesini azaltmaya yönelik oluşturulan formal tedbirlere uyulmasına yardımcı olmaktadır. Bu düşünce yapısına sahip olan birçok şirket telework çalışma stiline, COVID-19 krizine karşın etkili bir çözüm olarak bakmakta ve sayıca gün be gün artmaktadır. Pandemi ile birlikte bazı yöneticilerin ve kuruluşların telework sistemine adaptasyonu kolay olmakta işgörenlere bu sistemi aşılamakta zorluk çekmemektedir. Hızlı ve kolay adaptasyon uygulayamayan kuruluşlar ve yöneticiler ise işgörenlerin iş akdinin sonlandırılmakta ya da belirli süreli karşlıksız izin sürecine çıkmaya yönlendirmektedir. Bu noktada salgının, şirket ekonomik faaliyetlerinin devam ettiği kurumlarda olumlu, sürekliliğin bozulduğu, ekonomik faaliyetlerin kesintiye uğradığ1 kurumlarda ise olumsuz etkilendiği sektörel alanlar ve iş kolları bulunmakta, piyasa gelgitlerinin yoğun yaşandığ1 görülmektedir.

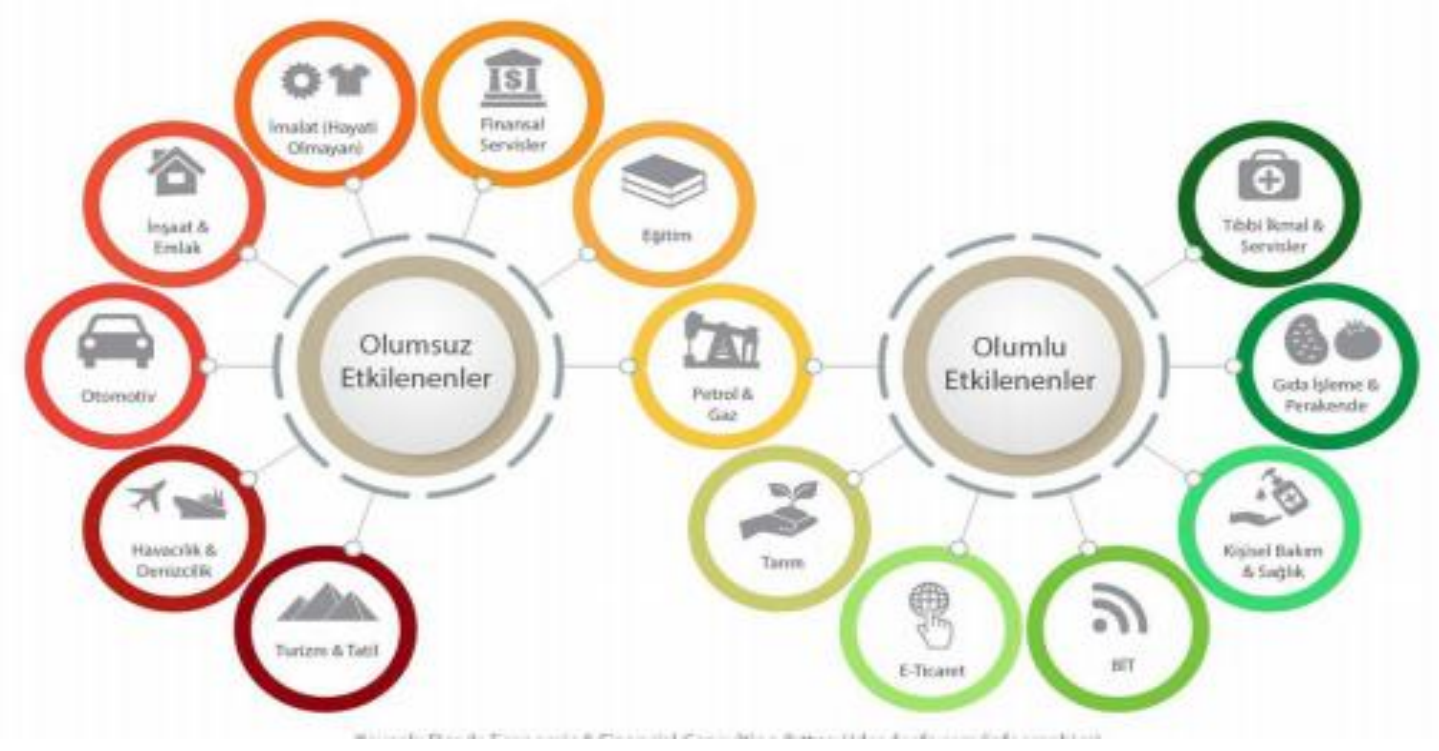

Şekil 1. COVID-19 krizinin potansiyel kazanan ya da kaybeden sektörleri (TÜBA, 2020, s. 97)

İşveren ve işgörenler açısından iş gücü ve yapılanmada yaşanan varyasyonlara uyum sağlayabilmek, yeni şartlardan üst düzeyde faydalanabilmek oldukça önem arz etmektedir. Bu yönden incelendiğinde telework çalışma sistemi, iş- yaşam balansını korumak veya oturmuş bir düzende işleyişin devamını sağlamak adına belirli durum ve koşulların yumuşatılmasını ya da dönüştürülmesini ön görmektedir. COVID-19 pandemi süresince iş etkinliklerini sürdürebilen yöneticiler ve kuruluşlar telework çalışma sistemini makul gerekçelerden ötürü çekici bulmaktadır.

- İsgören shhhat ve emniyetinin güvenceye alınması

- İşgören sadakatinin sağlanarak verimli, potansiyeli yüksek çalısanların kazanılması

- İş-yaşam balansının sağlanması. 


\section{İşçi ve İşveren Örgütlerinin Yaklaşımları}

COVID-19 pandemi sürecinde çalışma yürütürken cep telefonu, tablet, bilgisayar ve telekonferans gibi iletişim araçlarını kullanan "bilgi çalışanları" çözümsel ve entelektüel olan görevlerine telework sistemi ile devam ettirmişlerdir. Öte yandan COVID-19 pandemi süreci ortalarında, sağlık çalışanları başta olmak üzere emniyet ve güvenlik personelleri, kargo teslimatçları, depo işçileri ve kasiyerler gibi belirli meslek grupları kamuda virüse maruz kalma ve ailelerine bulaştırma riskini göze alarak işe gidip gelmeye devam etmiş “ideal çalışan” olmaya mecbur bırakılmışlardır (Thomason ve Williams, 2020).

Telework sistemi COVID-19'un bulaşma riskini minimize edebilmek için tüm dünyada çeşitli yöntemlerle uygulamaya koyulmuştur. Korona virüsün yakın münasebet ve solunum yoluyla bir insandan diğerine geçtiğinin tespit edilmesiyle sosyal mesafe olarak adlandırdığımız koruyucu tedbirler, "sosyal izolasyon" kapsamında içtimai hayat ve iş yaşantısında uygulanmaya başlanmışır (Fadinger ve Schymik, 2020, s. 1). COVID-19 menşeli yürütümü gerçekleştirilen telework çalışma sistemi aynı zamanda işgören ve işveren/kurum açısından birtakım avantaj ve dezavantajlanı beraberinde getirmiştir.

Tablo 1. Tele-çalşsmann Avantajlar

\begin{tabular}{ll}
\hline İşgören açısından & İşverenler ve kurumlar açısından \\
\hline Esneklik ve otonomi & Artan verimlilik \\
İşsizliğe bir alternatif olması & Yaşam kalitesinin artması \\
Şahsi özgürlük & Ofis-mekan tasarrufu \\
Bireysel çalış̧ma & Emek veriminin artması \\
Sarfiyatların azalması & İşilişkilerinde elastiki yapi \\
İş problemlerinin azalması & Daha iyi müşteri hizmeti \\
Yolculuk zamanının ve maliyetlerinin azalması & Motivasyonun artması \\
Geliştirilmiş iş firsatları & Maliyetin azaltılması \\
Yerel faaliyetlere daha fazla katılım & Daha az devamsızlık \\
İș ve aile yaşamı arasındaki dengenin kurulması & Nitelikli işgücü \\
\hline
\end{tabular}

Tablo 2. Tele-çalşsmanm Dez̧avantajlar

\begin{tabular}{ll}
\hline İşgören açısından & İşverenler ve Kurumlar açısından \\
\hline Kurumsal zorluklar & Kurumsal yapı değişiklikleri \\
Takım çalışmasının zorlaşması & Donanım maliyetleri \\
Statü kaybı korkusu & Görev tahsis hataları \\
Terfi sorunları & Çalışan motivasyonu \\
Psikolojik problemler & Teknolojiye erişim problemleri \\
Sosyal izolasyon & Çalışanların işi istismar etme korkusu \\
Teknolojik kaynakların eksikliği & Çalışanların izlenmesindeki zorluklar \\
İş ve ev yaşamı arasında denge sorunu & Çalışanların kontrolü ve güveni \\
Aile sorunlarının şiddetlenmesi & Kurumsal deneyim eksikliği \\
İşkolikliğe eğilim & Sendikaların olumsuz yaklaşımları \\
Meslektaşlardan izole olma & Sigorta, sağlık ve güvenlik sorunları
\end{tabular}
Kaynak: (Meşhur, 2007, s. 267)

Telework sistemine ilişkin en dikkat çeken avantaj çalışanların esneklik sahibi olabilmeleridir. İşgören, çalışma saatini ve zamanlamasını kendi belirleyerek şahsına ayrıcalık tanıyabilmektedir. Bu noktada işgören şahsı için en verimli saat diliminde rahatlıkla çalışabilmekte, işe geç kalma, yönetim ile sürtüşme ya da çalışma arkadaşları ile takım stresleri yaşama gibi olumsuz halütavırlara maruz kalmamaktadır. Öte yandan bu esneklik, işgören için kesif iş temposunu beraberinde getirmekte, denetim ve kontrolde aksaklıklar yaşanmasına ve işi yetiştirememe kaygısı gibi olumsuzluklar ile iş stresine sürükleyebilmektedir. Telework çalışma yönteminde düzensizlik mevcuttur. İşin belirli bir zamanda yapılması, mesai saatlerine uyma gibi bir sorumluluk içermediğinden, işi erteleme de beraberinde gelebilmektedir (Tutar, 2007, s. 125). Aynı zamanda bu çarpışıklık aşırı çalışma sorununa da mahal verebilmektedir. İşveren açısından bakıldığında esneklik, çalışanların üretkenliğini artırarak, işgörenlerin rutin ofis işleri yerine müşteriye daha fazla enerji ve zaman ayırma eğiliminde olmalarını sağlamaktadır. İşe devamsızlık probleminin telework sistemi aracılı̆̆ıyla çözüme kavuşması da işveren açısından oldukça olumlu bir etkendir. Bu çalışma sisteminin yapıcı taraflarından bir tanesi de ulaşım meselesinin işveren ve işgören arasında sorun olmaktan çıkmasıdır. Trafiğin yoğun olduğu kesimlerde ikamet eden bireyler için ciddi zaman tasarrufu sağlayan bu sistem trafik stresiyle karşı karşıya kalmayan çalışan motivasyonunun ivme kazanmasında olumlu bir kriterdir. Ayrıca kurum ve işveren için önemli bir gider skalası olan ulaşım masraflarının azalması şirket maliyetinde mühim yer tutmaktadır. Bazı kurum ve kuruluşlar, normalde ulaşım ücreti hakkı olan bireylere ek ücret olarak bu 
ulaşım tasarrufunu iletirken, bazıları ise bu tasarrufu şirket paylarına saklamaktadır. İşgören için zaman artırımı sağlayan bu nizam yöneticiler için gider daralması anlamına gelmektedir.

Telework çalışma sisteminde çalışanların; ekipman yetersizliği, internet çekim gücü zayıflığı, elektrik kesintisi gibi dış etkenler nedeni ile teknik ya da teknolojik bir sorunla karşılaşma olasıllğı oldukça yüksektir. İşgören bu sistemi yürüttügü herhangi bir alanda teknik bir aksaklık ya da teknolojik bir kesinti deneyimliyorsa ne yapacağı, nasıl bir yol izleyeceği tamamılla kendi sorumluluğundadır ve tek başına üstesinden gelmesi beklenmektedir. Bu noktada şirket ve kurumlara ait kurumsal/fiziksel işyerlerinde çalışan bireyler teknolojik ekipmanlar kullanılarak bu problemleri ekip arkadaşlarıyla veya firmanın desteği ile çözebilirken, telework yönteminde bireysel hareket etmekte, aynı zamanda çalışanlar için para ve vakit kaybına yol açmaktadır (Brown ve Duguid, 2001, s. 75).

Çalışma biçiminin değişimi ile işgören ve işveren arasındaki iş ilişkisinin bilvasıta usullerle kurulması nedeniyle tele çalışanların iş güvencesi yasal himaye alanı dışında kalmaktadır (Erdut, 1998 , s. 19). Bilhassa genç bireyler ve kadınlar telework çalışma sisteminde kesif olarak istihdam edildikleri için sosyal güvenlikte var olan boşluklardan ötürü zarar görmektedir (Parlak, 2004, s. 214). Aynı zamanda ofis/çalışma merkezi bir güvenceyi temsil ederken, telework sisteminde çalışan bireyler mekândan ayrilarak izole bir ortamda çalıştırılmaya itilmesi güvencesizliğe yol açmaktadır (Tutar, 2007, s. 131). Telework sistemi aracilığıyla işgörenin iş sağllğ̆ ve güvenliğinin yanı sıra hanede bulunan bireylerin özellikle varsa çocukların sağlık ve güvenliklerinin korunmasi da gerekmektedir. "Evdeki havann kalitesi, yangzn teblikesi, ergonomik teblikeler, aydnlatma, is stresi, yaralanma ve hastallk taæminatı gibi konularda önemli sorunlarla karşılaşılmaktader" (Tokol, 2003). Bu gibi hususlarda işveren / kurum ya da devlet tarafinca hanenin işgören sağllğı ve emniyeti açısından düzenlenmesi ve muayen aralıklarla denetlenmesi gerekmektedir. Söz konusu bu durum beraberinde özel yaşamın ihlaline yönelik birtakım düşünceleri de ortaya çıkarmaktadır.

İşörenlerin iş/ofis ortamından ırak kalmaları kariyer planlamalarında ciddi belirsizliklerle karşılaşmalarına sebebiyet vermektedir. Çünkü yürütülen organizasyonlarda kurulan bağ sanal oluşturulmakta ve bu vaziyet kariyer planlamalarında birtakım sorunlara, öngörülemez bir gidişata yol açmaktadır. Örgütsel öğrenmeyi de olanaksız hale getiren bu durum ofis çalışanları ve telework sisteminde çalışan bireyler arasında firsat eşitsizliğine neden olmaktadır (Aksoy, 2012, s. 405). Ayrıca işveren ve kurumun sürekli ve düzenli gözetimi dışında bir oluşumu simgeleyen telework çalışma sisteminde işgörenlere materyal temini, ifa edilen işin teslimi ve faaliyetlerin denetimden geçirilmesi gibi ek hizmetleri ortaya çıarmaktadır (Yavuz, 1995, s. 63).

Telework çalışma sisteminin nafi olduğunu düşünen ve tele çalışmayı uygulayan organizasyonların \%5’i ofis mekân tasarrufu, \%35'i işgörenlerin esnek olmas1, \%10’u maliyetlerdeki azalma, \%35'i faaliyet verimliliğinin artması ve \%15'i nitelikli eleman istihdamı nedeni ile tele çalışmaya ilişkin tutumlarını olumlu olarak dile getirmişlerdir. Tele çalışmanın nafi olmayacağına inanan organizasyonlar ise işlerin \%70'inin örgütlenmeye uygun olmaması, \% 23,3'ü işgörenlerin denetlenememesi, \% 6,6's1 ise kurumsal yapıda değişiklik gerektirmesi nedeni ile tele çalışmaya ilişkin tutumlarını olumsuz olarak yansıtarak tele çalışmayı tercih etmediklerini belirtmişlerdir (Meşhur, 2010, s. 14).

Telework sistemi genel kapsamı ile işveren/kurum açısından nitelikli personeli daha kolay temin etmek, işe devamsızlığı azaltmak, icar, ulaşım gibi birtakım maliyetleri indirgeyen, randıman seviyesini artıran bir çalışma biçimidir. İşgören açısından ise zaman tasarrufu, ulaşım maliyetlerinde azalma, iş stresinde azalma, iş yerinden 1 rak, özerk çalışabilme ve aile sorumluluk balansını kurabilme imkanı sunmaktadır. Ancak telework sistemi işgörenlerinin teknik problemlerle karşılaşacakları ve içtimai hayatlarında aksaklık yaşayacakları düşünülmektedir. Bu nedenle telework sistemi işgörenlerin tinsel anlamda da etkilenebileceği bir çalışma biçimidir. Telework her çalışan için uygun bir çalışma biçimi olmayabilir. Bunun için telework sisteminde en önemli unsurlardan biri gönüllülüktür.

Bu kapsamda istenmeyen sonuçları önlemek ve salgın sürecini sosyal mesafe ve izolasyon kurallarına uyarak sağlıklı bir şekilde yönetebilmek için uzaktan çalışma yürüten işgörenlerin ve işverenlerin dikkat etmesi gereken önemli hususlar aşağıda ele alınmaktadır (Bouziri, Smith, Descatha, Dab ve Jean, 2020, s. 509):

- Çalışma arkadaşları ve yöneticiler ile iletişim gücünün arttırılması,

- İhtiyaç duyulduğunda uzaktan çalışma hususunda esneklik sağlanabilmesi,

- Uzaktan çalışmayı destekleyecek güncel uygulamaların ve e-posta kutusunun sürekli takip edilmesi, 
- Günlük zamanın etkin bir şekilde planlanarak çalışma saatleri ve kişisel zamanın ayrılması,

- Özverili ve düzenli bir çalısma alanının oluşturulması,

- Dikkatin dağılmaması, odaklanma sorunları yaşanmaması için görevlerin ne olduğunun belirlenmesi ve rol çatı̧masının önlenmesi için sorumluluk paylaşımının yapılması,

- Etik ve uygun bilgi paylaşımları yapılarak arkadaş ve meslektaşlar ile bağ güçlendirilmesi,

- Uzaktan çalışırken işini anlamlı hale getirmesi,

- İşi ile ilgili, uzaktan çalışma hakkında gerektiğinde destek talep etmesi,

- Bireylerin COVID-19 sürecinde karşılaştıkları değişim ve dönüşüm faaliyetlerine (uzaktan eğitim, uzaktan çalışma, karantina, sokağa çıkma kısıtlaması) verdikleri tepkiler belirlenmeli ve beklenmedik durumlarda insanların değişime hazır olma durumlarını arttıracak tedbirler alınmalıdır.

\section{Psiko - Sosyal Sorunların Çalışan Verimliliği ile İlişkisi}

Tarih boyunca deneyimlenmiş olan salgınlar iktisadi, içtimai ve toplumsal varlık üzerinde çok geniş etkilere yol açmış, devletlerin yıkılışını hızlandırmış, derebeylikleri göçürmüş, süer sayılarını azaltmış, harplerin mağlubiyetle sonuçlanmasına zemin hazırlamıştır. Ziraat alanında işleyecek çalısan bulunamayışından ötürü özellikle Avrupalıları keşiflere yönlendirmiş ve çeşitli temel düzey ziraat teknolojilerini geliştirmiş, insanların salgınlardan korunmak için kent merkezlerinden köylere, yazlık alanlara göçünü ve buralarda yaşam alanları oluşturmalarını sağlamıştır (TÜBA, 2020, s. 79). Neredeyse 1 yıldır tüm yerküreyi çevreleyen ve bütün dünyanın gündeminde yer edinen COVID-19 salgını benzer şekilde bıraktığı emarelerle tarihte mühim bir hadise olarak yerini alırken, toplumsal yaşam üzerindeki hükümleri uzun süre devam edecektir. Bu yüzdendir ki küresel pandemiler, doğal afetler ve savaşların bireyler üzerinde derin toplumsal travmalara neden olmaktadır. Böyle dönemlerde stresle ilişkili rahatsızlıkların baş gösterdiği görülmektedir (Bozkurt, 2020, s. 130).

Pandemi sürecinde toplumsal yaşamda gelir dağılımlarının, statü farkllıklarının değersiz hale geldiği, insanların belirli bir mekân içerisinde kapalı kalmak durumunda olduğu, tedbir amaçlı da olsa yasaklar kapsamında sosyal yaşamın kısıtlanarak sınırlandırıldığı bir süreçle karşı karşıya gelindiği gözlemlenmektedir. Bu nedenle COVID-19 salgınının insan sağlığı üzerindeki yansımalarının yanı sıra toplumsal, sosyolojik ve psikolojik değerler üzerinde de etkisini görmek mümkündür. Toplumun önemli bir seksiyonu hastalik nedeniyle daha kaygill, daha paranoyak, kompulsif ve depresif bir ruh haline bürünmüştür. Toplum genelinde huzursuzluğun arttığı, gündelik işlerin yapılamaz hale geldiği, uyku kalitelerinin bozulduğu, kontrol mekanizmasının çöktüğ̈̈, virüs kapma korkusunun had safhaya ulaştığı, sürekli olarak bitkinlik hissedildiği ve güven skalasının düştüğü görülmektedir.

COVID-19 sürecinde yaşanan stres, gerginlik ve artan kaygı bozuklukları ile telework çalışma sistemi işgörenlerinin verimliliğindeki varyasyonlar, iki faktör arasındaki yakın ilişkinin varlığını ortaya koymaktadır. Ölüm/mikrop kapma korkusu, geçim gailesi. Psiko-sosyal problemler ivme kazandıkça telework sisteminde çalışanların verimliliklerinde büyük ölçüde azalma görülmekte, iş- yaşam döngüsü zedelenmekte ve variyet standardizasyonu düşmektedir.

Kamu sağlı̆̆ının korunması amacıyla uygulanan tedbirler neticesinde süregelen alışkanlıkların her ne kadar geçici olarak adlandırılsa bile belki de kalıcı bir şekilde değişeceği öngörülmektedir (TÜBA, 2020, s. 11). Bu nedenle eğitim ve iş hayatı alanları başta olmak üzere COVID-19 pandemisinden en çok etkilenen sektörlerde sosyal araştırmaların yapılması, beklenmedik durumlar karşısında hazırlıklı olma konusunda önem arz etmektedir.

\section{Dijitalleşme ve Verimlilik}

COVID-19 pandemisi tüm dünyada olduğu gibi Türkiye'de de bireyleri belirli bir mekâna bağlı kalmak durumunda bırakmış, iş merkezlerinin önemli bir kısmını çalışamaz hale getirmiştir. Yerküreyi 2019 yılının sonlarına doğru ekseni içine alan, 2020 Mart ayında ise Türkiye'de ortaya çıkan salgın nedeniyle işgörenlerin büyük bir kesimi işlerini işveren ile karşılıklı mutabakata vararak uzaktan/online yürütmek durumunda kalmıştır. Telework çalışma sistemine uygun işler ve eğitim makro ölçüde yapılanmaya girmiş ve dijitalleşmiştir. Bireyler yeni bilgi, iletişim teknolojilerini ve imkânlarını kullanarak iş akışlarını uzaktan yürütmeye başlamış, yeni normalde teknoloji ve verimlilik en dikkat çeken kavramlardan olmuştur. 
Max Weber (1985), kapitalizmin gelişim sürecinde işyerinin evden ayrılmasına özel bir anlam yüklemiştir. Ev ile işin birbirinden ayrılması, modern toplumun yaşama, çalışma ve düşünme biçimlerini derinden etkilemiştir. Geç kapitalizmin online/dijital çalışma düzeninde işin önemli bir bölümü evde yapılabilir hale gelmiştir. Bir diğer ifade ile işyeri ve ev yeniden bir araya gelmeye başlamıştır. COVID-19 pandemisi, çalışma hayatında dijitalleşmeyi mecbur kılmış ve dijitalleşmeyi hiç olmadı̆̆ kadar hızlandırmışır. Bazı ülkelerde işlerin üçte birinden fazlası evde yapılabilir hale gelmiştir (Dingel ve Neiman, 2020, s. 9).

Telework çalışma sistemi dijital dönüşüme önemli ölçüde tesir etmiş, Zoom ve Slack gibi uygulamaların kullanıcı sayıları 10 milyonlardan 100 milyonlara çıkmışır. Uygulama kullanıcılarının sayısal verilerinin yükselme nedeni pandemi süresince işgörenlerin telework aracilığtyla toplantı ve müzakerelerini dijital platformalar üzerinden yürütmeleridir. Dijital uygulamalar üzerinden ders anlatılmakta, toplantılar yapılmakta, sınavlar gerçekleştirilmekte, konserler verilmekte ve müzeler gezilebilmektedir (Dockery ve Sherry, 2020, s. 3). İlkokul, ortaokul, lise ve üniversitelerin yüz yüze eğitim sürecine ara vermesiyle öğretim üyelerinin dersleri uzaktan/online olarak öğrencilere aktarması ve eğitim yapılanmasını bu çizgide ilerletmesi gerekmektedir. Eğitim gibi daha birçok sektör telework çalışma sistemine ayak uydurarak, yeni yapılanmaya geçirilmiştir. Bu hal işgörenlerin performans ve verimliliklerinde olumlu ve olumsuz kazanımları beraberinde getirmiştir.

Telework çalışma sistemi içerisindeki yürütümleri uygulayabilme yetkinliği olan işgörenler yeni düzenin getirdiği kolaylık ile bu konumun pozitif kazanımlarını deneyimlerken, teknolojiyi kullanmada noksan kalan ve yetersizlik yaşayan işgörenler, iş- yaşam dengesini kuramamanın yanı sıra tinsel olarak bu durumun ortaya çıkardığı negatif etkenlerle de başa çıkmak zorundadır. Bir diğer yönüyle işgörenlerin esnek çalışmaya dayalı uzun süreli ve düzensiz çalışma saatleri ailelerine daha az zaman ayırmalarına neden olurken aile içi ilişkilerle ciddi problemlere yol açmaktadır. Bu durum iş ve aile yaşamlarından kaynaklanan rol arzu-taleplerinin bazı yönleriyle birbirleriyle uyumsuzluk yaşanması durumu olarak ifade edilebilmektedir (Greenhaus ve Beutell, 1985, s. 80). Çalışan genel yapısında moral bozukluğuna, motivasyon düşüklüğune ve strese bağlı duygu değişimlerine neden olacağından işgören başarım ve randımanı olumsuz etkilenecektir. Aynı zamanda telework çalışma sistemindeki işgörenler, faaliyet kapsamları boyunca cep telefonu, tablet, bilgisayar ve benzeri iletişim teknolojisi araçlarını yüksek oranda kullanması nedeniyle çeşitli rahatsızlara maruz kaldıkları gözlemlenmektedir. Omurga, omuz, el, bilek, kol kasları ve parmaklarda belirli rahatsızlıklar görülmektedir. Teknolojik aletlerin yaydığı radyoaktif dalgalara uzun süre maruz kalan işgörenlerde gözlerde yanma, kızarıklık, bulanıklık, yorgunluk, kaşıntı ve çift görme gibi problemler baş göstermektedir. Bu rahatsızlıklar işgörenlerin performans ve verimliliğinde önemli etkenlerden bir kaçıdır (Ersöz ve Özmen, 2020, s. 175). Ayrıca çalışma saatleri süresince işle ilgili olmayan amaçlar için internet kullanımı olarak tanımlanan bir kavram olan siber aylaklık, işgörenlerin işyerinin sağladığı olanakları kullanarak, çalışma saatleri içerisinde kişisel işlemlerine zaman ayırmaları, iş yerinde bilinçli olarak internette zaman kaybetmeye yönelik eylemler anlamına gelmektedir (Lim, 2002). Siber aylaklığın olumsuz sonuçları ile ilgili alan yazın incelendiğinde genel olarak verimliliği düşürdüğü görülmektedir (Eröz, 2020, s. 198). Bu nedenle çalışanların performans ve verimliliği direkt olarak olumsuz etkilenmektedir.

Bilişim teknolojilerinin ilerlemesi ve internetin yaygınlaşması ile işgörenler endüstriyel çağdan, bilgisayar ve bilişim çağına yani dijital çağa dönüşüm yaşamıştır. Dijitalleşme işgörenlere çalışacakları mekân ve zamanı istedikleri gibi seçebilme ayrılacılığı tanımaktadır. Aynı zamanda iş planlamaları çalışanların yaşam tarzlarına göre ayarlanabilmektedir. İşgören ve işverenlerin daha aktif ve verimli bir performansla çalışmaları için bilişim teknolojilerine yönelik gelişmeleri yakından takip etmeleri gerekmektedir. Dijital dünyanın ve yapay zeka teknolojilerinin entegre edildiği bu dönem telework sisteminde çalışanların hayatını zorlaştırmaktan öteye niteliklerini değiştirmeli ve geliştirmelidir. Telework sisteminde çalışanların yaşam tarzlarını dijitalleşmeye dönüştürerek hem verimlilik hem de performanslarının artırılmasını sağlamak, dijitalleşme sürecinde başarılı olma hususunda büyük etkiye sahip olacaktır (Ersöz ve Özmen, 2020, s. 178)

\section{Yöntem}

\section{Araştırmanın Amacı}

COVID-19 krizi ile yeni bir boyut kazanan telework çalışma sistemi dijitalleşmenin de etkisi ile yeni bir nitelik kazanmıştır. Pek çok sektöre uyarlanarak benliğini bulan bu sistemde COVID-19 krizi nedeni ile önemli sayıda çalışan uzaktan çalışma (telework) sistemine geçmiş ve yeni bir yapılanma içerisine girmiştir. 
$\mathrm{Bu}$ araştırma çalışanların tele çalışma algıları hakkında bilgi edinmek, dijitalleşmeyi deneyimleyen işgörenlerin çalışma hayatlanındaki iş- yaşam balansını gözlemlemek ve iletişimsel boyutunu incelemek amaciyla yürütülmektedir.

\section{Araştırmanın Önemi}

Literatürde yalnızca "Telework", "Dijitalleşme" ya da "COVID-19 Krizi” üzerine farklı alanlarda araştırmalar mevcut olsa da bu kavramların bir araya gelerek yeni bir koalisyon oluşturması nedeniyle araştırmaların tatmin edici düzeyde olduğu söylenememektedir. Bu noktada taze bir araştırma ile literatüre katkıda bulunmak, başka bir bakıș açısı ile var olan durumu değerlendirebilmek önemlidir. Bu çalışma, hizmet sektörünün mutena bir kolu olan çağr1 merkezi sistemlerinde işgören 25-30 yaş skalasındaki bireylerin tecrübe ettikleri kriz, çalş̧ma sistemi ve dijitalleşmeye ortak bir noktadan bakarak iletişim alanında farkındalık oluşturabileceği ve akademik anlamda pay edinebileceği düşünülmektedir.

\section{Araştırma Evreni ve Örneklem}

Araştırma evreni ve örneklemini Twitter kullanıcısı olan ve çağrı merkezi sistemlerinde telework/uzaktan çalışma yöntemi ile işgören "25-30" yaş arası bireyler oluşturmaktadır. Araştırmada birinci elden veri toplama teknikleri arasında olan anket tekniğinden faydalanılmış, yapılan anket çalışması; rastgele örneklem yöntemiyle seçilen, aktif Twitter kullanıcısı olan ve çağıı merkezinde telework sistemiyle çalışan 25-30 yaş arası 300 kişinin katılımı ile sınırlandırılmışır.

\section{Veri Toplama Araçları}

Araştırmada nicel bir araştırma yöntemi olan "betimsel" ve "bağlantısal" araştırma modeli kullanılmaktadır. Betimsel araştırmalar, bir konudaki herhangi bir durumu saptamayı hedefleyen araştırma yöntemleridir. Betimsel araştırma, çalışılan konunun mevcut durumuna ilişkin hipotezleri test etmek için veya sorulara cevap bulmak için verileri toplamayı gerektiren bir modeldir. Betimleyici veriler, genellikle anket, gözlem, test veya görüşme gibi bilgi toplama yollarıyla elde edilmektedir.

Araştırma başlangıcında COVID-19 krizi, telework sistemi ve dijitalleşmeyi barındıran Baert ve çalışma arkadaşları (2020) tarafindan geliştirilen 30 soruluk bir anket Türkçeye çevrilmiş ve uygulanabilmesi için telework çalışma sisteminin en geniş alanda uygulandığı sektör taraması yapılmıştır. Elde edilen bilgiler sonucu araştırma sınırlandırılmış ve çağnı merkezi sistemlerinde işgören bireyler seçilmiştir. Twitter aracılı̆̆ ile rastgele örneklem yöntemi kullanılarak 25-30 yaş arası işgören çağrı merkezi çalışanlarına iletilmiş ve verilen bilgiler esas alınarak veri kodlamaları ortaya koyulmuştur.

\section{Verilerin Analizi}

Çalışma kapsamında örneklem olarak belirlenen 25-30 yaş arası çağnı merkezi işgörenlerine anket uygulanmış, 300 kişinin katılımı sonucunda veriler toplanmıştır. İşgörenlere hangi kriterlere göre işaretleme yapacağ1 ve alg1 yönetimleri ile ilgili detaylı bilgilendirme anket girişinde verilmiş ve bu bilgiler ışığında doğruluk ve gerçeklik düzeyi yüksek bir kodlama yapmaları istenmiştir. Bilgiler toplandıktan sonra elde edilen veriler SPSS 22.0 istatistik programına yüklenmiş ve veriler için uygun analizler yapılmıştır.

Toplanan bilgiler analiz edilirken betimsel istatistik analiz teknikleri olarak adlandırlan frekans, yüzde ve ortalama çözümlemeleri kullanılmıştır. Betimsel istatistikler bir değişkene ilişkin sayısal değerlerin toplanmasi, betimlenmesi ve sunulmasına olanak sağlayan istatistiksel işlemleri tanımlamaktadır. $\mathrm{Bu}$ doğrultuda verilerin işlenmesinde alınan değerler her bir soru için tablo halinde aktarılarak yorumlanmıştır. 300 katılımcının olduğu ankette 5'li Likert ölçeği kullanılmıştır. Likert ölçekte yer alan maddelere katılım düzeyini belirlemek için ilk bölümde "Kesinlikle olumlu etki" (5), "Olumlu etki" (4), "Ne olumlu ne olumsuz etki" (3), "Olumsuz etki" (2), "Kesinlikle olumsuz etki" (1) olacak şekilde derecelendirme yapılmıştır. İkinci ve üçüncü bölüm ise "Tamamen katılıyorum” (5), "Katıllyorum” (4), "Kararsızım” (3), "Katılmıyorum" (2) ve "Tamamen katılmıyorum" (1) şeklinde sınıflandırılmıştır. Sonuçların geçerliliğini ve güvenirliğini ortaya koyabilmek adına veriler tarafsız değerlendirmeye tabii tutulmuş ve herhangi bir değişikliğge gidilmemiştir.

\section{Bulgular}

Araştırma bulgularının değerlendirilebilmesi adına 30 soruluk bir anket çalışması yapılmıştır. Üç bölümden oluşan bu ankette ilk bölümde, telework çalışma sistemi hakkında çağrı merkezi çalışanlarının (25-30) genel görüşlerini kariyer yönleri üzerinden araştırmak amaçlanmaktadır. İkinci bölümde, 
işgörenlerin telework deneyimlerinin saptanması ve hayata yerleşim sürecinin algılanması amaçlanırken üçüncü bölümde ise dijitalleşme ve telework yapısının şu anda nasıl olduğu ve geleceğe nasil adapte edileceği gözlemlenmektedir. Anket soruları minimum 1 "tamamen katılmıyorum" - maximum 5 "tamamen katılıyorum" değer aralığında ifade edilmektedir.

Tablo 3. Lütfen Cinsiyetinizi Seçiniz $(n=300)$

\begin{tabular}{ccccc}
\hline Valid & Frequency & Percent & Valid Percent & Cumulative Percent \\
\hline Erkek & 129 & 43,0 & 43,0 & 43,0 \\
Kadın & 171 & 57,0 & 57,0 & 100,0 \\
\hline
\end{tabular}

Tablo 3. incelendiğinde katılımcıların \%43’ünün (129 kişi) erkek, \%57’sinin (171 kişi) kadın olduğu tespit edilmiştir. Ankete toplamda 25-30 yaş aralığına sahip aktif çalışan 300 çağrı merkezi işgöreni katılım sağlamışır.

\section{A.1. "Genel olarak tele-çalı̧̧manın çeşitli kariyer yönleri üzerinde algılanan etkisi”}

Tablo 4. İssimden Genel Memnuniyetim Üz̧erine Etkisi $(n=300)$

\begin{tabular}{lcccc}
\hline \multicolumn{1}{c}{ Valid } & Frequency & Percent & Valid Percent & Cumulative Percent \\
\hline Kesinlikle olumsuz etki & 11 & 3,7 & 3,7 & 3,7 \\
Olumsuz etki & 28 & 9,3 & 9,3 & 13,0 \\
Ne olumlu ne olumsuz etki & 63 & 21,0 & 21,0 & 34,0 \\
Olumlu etki & 138 & 46,0 & 46,0 & 80,0 \\
Kesinlikle olumlu etki & 60 & 20,0 & 20,0 & 3,7 \\
\hline
\end{tabular}

Katılımcıların \%66's1 (198 kişi) işinden genel bir memnuniyete sahip olduklarını ifade etmektedir. Bu çalışma sisteminde iş memnuniyetinin düşük olduğunu belirtenlerin oranı ise \%13 (39 kişi) tür. Katılımcıların \%21’i (63 kişi) fikir beyan etmeyerek ne olumlu ne olumsuz etki ifadesini kullanarak genel iş memnuniyeti hakkında bilgi vermemektedir. Genel memnuniyet yüzdesine bakıldığında işgörenlerin telework sisteminden hoşnut oldukları söylenebilmektedir.

Tablo 5. Terfi Şansim Üzerine Etkisi $(n=300)$

\begin{tabular}{lcccc}
\hline \multicolumn{1}{c}{ Valid } & Frequency & Percent & Valid Percent & Cumulative Percent \\
\hline Kesinlikle olumsuz etki & 9 & 3,0 & 3,0 & 3,0 \\
Olumsuz etki & 43 & 14,3 & 14,3 & 17,3 \\
Ne olumlu ne olumsuz etki & 177 & 59,0 & 59,0 & 76,3 \\
Olumlu etki & 59 & 19,7 & 19,7 & 96,0 \\
Kesinlikle olumlu etki & 12 & 4,0 & 4,0 & 100,0 \\
\hline
\end{tabular}

Katılımcıların \%23,7’si (71 kişi) telework sistemi içerisinde terfi şansına eriştiğini aktarmaktadır. Terfi firsatının olmadığını beyan eden katılımcıların oranı 17,3 (52 kişi) tür. Terfi şansının ne olumlu ne olumsuz etkisi olduğunu düşünenlerin oranı ise \%59 (177 kissi) dur. Katıllımcıların büyük bir bölümünün bu soruda çekimser kaldığı görülmektedir.

Tablo 6. Mesleki Gelişimim Üzerine Etkisi ( $n=300)$

\begin{tabular}{lcccc}
\hline \multicolumn{1}{c}{ Valid } & Frequency & Percent & Valid Percent & Cumulative Percent \\
\hline Kesinlikle olumsuz etki & 10 & 3,3 & 3,3 & 3,3 \\
Olumsuz etki & 53 & 17,7 & 17,7 & 21,0 \\
Ne olumlu ne olumsuz etki & 112 & 37,3 & 37,3 & 58,3 \\
Olumlu etki & 99 & 33,0 & 33,0 & 91,3 \\
Kesinlikle olumlu etki & 26 & 8,7 & 8,7 & 100,0 \\
\hline
\end{tabular}

Katılımcıların \%41,7’si (125 kişi) mesleki gelişim sürecinde telework sisteminin devamlllı sağladığını ifade etmektedir. Telework çalş̧ma sisteminin mesleki gelişim sürecinde olumsuz etkisinin olduğunu düşünenlerin oranı \%21 (63 kişi) dir. Bu sistemin iş gelişim sürecine herhangi bir etkisinin olup olmadığını beyan edenlerin oranı ise \%37,33 (112 kişi) tür. Bu oranlara bakıldığında şirket bazında, uzaktan çalışma yürütülürken dahi iş görenlere gelişim firsatı sunulduğu varsayılabilir. 
Tablo 7. Görevleri Yerine Getirmedeki Verimliliğim Üzerine Etkisi (n=300)

\begin{tabular}{lcccc}
\hline \multicolumn{1}{c}{ Valid } & Frequency & Percent & Valid Percent & Cumulative Percent \\
\hline Kesinlikle olumsuz etki & 11 & 3,7 & 3,7 & 3,7 \\
Olumsuz etki & 13 & 4,3 & 4,3 & 8,0 \\
Ne olumlu ne olumsuz etki & 74 & 24,7 & 24,7 & 32,7 \\
Olumlu etki & 156 & 52,0 & 52,0 & 84,7 \\
Kesinlikle olumlu etki & 46 & 15,3 & 15,3 & 100,0 \\
\hline
\end{tabular}

\%8’lik (24 kişi) bir oran ile bazı katılımcıların görevleri yerine getirme verimliliğinin olumsuz etkilendiğini belirtirken \%24,7 lük (74 kişi) bir grubun ne olumlu ne olumsuz etkiyi işaretleyerek çekimser kaldığı gözlemlenmektedir. Lakin \%67,3’lik (202 kişi) bir oranlama ile katılımcıların yüksek çoğunluğu görevlerdeki verimliliğinin faik olduğunu belirtmektedir.

Tablo 8. İsverenime Bağllhk Hissim Üzerine Etkisi (n=300)

\begin{tabular}{lcccc}
\hline \multicolumn{1}{c}{ Valid } & Frequency & Percent & Valid Percent & Cumulative Percent \\
\hline Kesinlikle olumsuz etki & 11 & 3,7 & 3,7 & 3,7 \\
Olumsuz etki & 34 & 11,3 & 11,3 & 15,0 \\
Ne olumlu ne olumsuz etki & 151 & 50,3 & 50,3 & 65,3 \\
Olumlu etki & 83 & 27,7 & 27,7 & 93,0 \\
Kesinlikle olumlu etki & 21 & 4,0 & 4,0 & 100,0 \\
\hline
\end{tabular}

Katıllımcıların \%34,7’si (104 kişi) bu süreçte işverenine bağllık hissinin arttığını beyan ederken, \%15’i (45 kişi) bu konuda olumsuz bir görüşe sahip olduğunu aktarmaktadır. \%50,33’lük (151 kişi) bir kesim ise ne olumlu ne olumsuz etki kriterini seçerek görüş bildirmemektedir.

Tablo 9. Iss Yasam Dengem Üzerine Etkisi (n=300)

\begin{tabular}{lcccc}
\hline \multicolumn{1}{c}{ Valid } & Frequency & Percent & Valid Percent & Cumulative Percent \\
\hline Kesinlikle olumsuz etki & 14 & 4,7 & 4,7 & 4,7 \\
Olumsuz etki & 68 & 22,7 & 22,7 & 27,3 \\
Ne olumlu ne olumsuz etki & 48 & 16,0 & 16,0 & 43,3 \\
Olumlu etki & 113 & 37,7 & 37,7 & 81,0 \\
Kesinlikle olumlu etki & 57 & 19,0 & 19,0 & 100,0 \\
\hline
\end{tabular}

Katılımcların \%56,7'si (170 kişi) iş-yaşam dengesinde telework sisteminin olumlu etkisinin olduğunu bildirmektedir. \%27,4'lik (82 kişi) bir bölüm bu düzenin yaşantısal olarak olumsuz etkisinin olduğunu ifade ederken \%16’lık (48 kişi) bir bölüm ise herhangi bir fikir beyan etmemektedir.

Tablo 10. Calısma Arkadaşlarm İle İliskkim Üzerine Etkisi (n=300)

\begin{tabular}{lcccc}
\hline \multicolumn{1}{c}{ Valid } & Frequency & Percent & Valid Percent & Cumulative Percent \\
\hline Kesinlikle olumsuz etki & 15 & 5,0 & 5,0 & 5,0 \\
Olumsuz etki & 76 & 25,3 & 25,3 & 30,3 \\
Ne olumlu ne olumsuz etki & 142 & 47,3 & 47,3 & 77,7 \\
Olumlu etki & 51 & 17,0 & 17,0 & 94,7 \\
Kesinlikle olumlu etki & 16 & 5,3 & 5,3 & 100,0 \\
\hline
\end{tabular}

Katılımcıların \%22,3’ü (67 kişi) telework sisteminde çalışma arkadaşları ile arasındaki ilişkinin olumlu olduğunu söylemektedir. \%30,3’ü (91 kişi) ise telework sisteminin çalışma arkadaşları ile olan ilişkisi üzerine negatif bir etkisinin olduğunu beyan etmektedir. \%47,3’lük (142 kişi) bir oran ile büyük bir çoğunluğu olumlu ya da olumsuz herhangi bir tesirinin olmadığını aktarmaktadır.

Tablo 11. İsle İlgili Stresimi En Aza İndirme Üzerine Etkisi (n=300)

\begin{tabular}{lcccc}
\hline \multicolumn{1}{c}{ Valid } & Frequency & Percent & Valid Percent & Cumulative Percent \\
\hline Kesinlikle olumsuz etki & 15 & 5,0 & 5,0 & 5,0 \\
Olumsuz etki & 27 & 9,0 & 9,0 & 14,0 \\
Ne olumlu ne olumsuz etki & 58 & 19,3 & 19,3 & 33,3 \\
Olumlu etki & 140 & 46,7 & 46,7 & 80,0 \\
Kesinlikle olumlu etki & 60 & 20,0 & 20,0 & 100,0 \\
\hline
\end{tabular}

Katılımcıların \%14’ü (42 kişi) işle ilgili stres yönetiminin negatif yönde etkilendiğini belirtmektedir. Ne olumlu ne olumsuz etkisi oldu diyenlerin oranı ise \%19,3 (58 kişi) tür. \%66,7'lik (200 kişi) bir kesim işle ilgili stres yönetiminin yüksek derecede olumlu etkilendiğini beyan etmektedir. Bu verilere bakıldı̆̆ında telework çalışma sisteminin iş ile ilgili stresi en aza indirgediği söylenebilmektedir. 
Tablo 12. Tükenmişlik İbtimalini En Aza İndirme Üzerine Etkisi (n=300)

\begin{tabular}{lcccc}
\hline \multicolumn{1}{c}{ Valid } & Frequency & Percent & Valid Percent & Cumulative Percent \\
\hline Kesinlikle olumsuz etki & 13 & 4,3 & 4,3 & 4,3 \\
Olumsuz etki & 40 & 13,3 & 13,3 & 17,7 \\
Ne olumlu ne olumsuz etki & 83 & 27,7 & 27,7 & 45,3 \\
Olumlu etki & 115 & 38,3 & 38,3 & 83,7 \\
Kesinlikle olumlu etki & 49 & 16,3 & 16,3 & 100,0 \\
\hline
\end{tabular}

Katılımcların \%54,6's1 (164 kişi), telework çalışma sisteminin tükenmişlik olasılı̆̆ını düşürdügünü belirtmektedir. \%17,6's1 (53 kişi) ise tam tersine tükenmişlik olasılığında negatif etki bıraktığını beyan etmektedir. \%27,67’si (83 kişi) tükenmişlik ihtimalinin en aza indirme fikri hakkında bir görüş aktarmamaktadır.

Tablo 13. İș Sirasindaki Konsantrasyonum Üzerine Etkisi ( $n=300)$

\begin{tabular}{lcccc}
\hline \multicolumn{1}{c}{ Valid } & Frequency & Percent & Valid Percent & Cumulative Percent \\
\hline Kesinlikle olumsuz etki & 11 & 3,7 & 3,7 & 3,7 \\
Olumsuz etki & 39 & 13,0 & 13,0 & 16,7 \\
Ne olumlu ne olumsuz etki & 66 & 22,0 & 22,0 & 38,7 \\
Olumlu etki & 139 & 46,3 & 46,3 & 85,0 \\
Kesinlikle olumlu etki & 45 & 15,0 & 15,0 & 100,0 \\
\hline
\end{tabular}

$\% 16,67$ 'lik (50 kişi) bir grup telework sisteminin iş esnasındaki konsantrasyon etkisini olumsuz yorumlarken \%22 lik (66 kişi) bir grup ise pozitif ya da negatif bir tesirinin olmadığını belirtmektedir. \%61,33'lük (184 kişi) bir değer ile katılımcıların birçoğu bu sistemin iş sırasındaki konsantrasyon hükmünün yüksek olduğunu söylemektedir. Bu değer yargisına istinaden işgörenlerin rahat çalısma koşullannda konsantrasyon verimliliğinin oldukça yükseldiğini söylemek mümkündür.

A.2. "COVID-19 krizi sırasında uzun süreli tele çalışmanın çeşitli yaşam ve kariyer yönleri üzerindeki algılanan etkisi”

Tablo 14. Korona Kriz̨i Nedeniyle Evde Daba Fažla Calhstığrm İ̧in Genel Olarak Memnunum (n=300)

\begin{tabular}{lcccc}
\hline \multicolumn{1}{c}{ Valid } & Frequency & Percent & Valid Percent & Cumulative Percent \\
\hline Tamamen katılmiyorum & 10 & 3,3 & 3,3 & 3,3 \\
Katılmiyorum & 38 & 12,7 & 12,7 & 16,0 \\
Kararsizim & 45 & 15,0 & 15,0 & 31,0 \\
Katiliyorum & 122 & 40,7 & 40,7 & 71,7 \\
Tamamen katilyyorum & 85 & 28,3 & 28,3 & 100,0 \\
\hline
\end{tabular}

COVID-19 krizi süresince çalışma aksını genel olarak evden yürütmekten hoşnut olan bireylerin oranı \%69 (207 kişi) dur. \% 16’lık (48 kişi) oran ile mikro bir kesim memnuniyetsizlik yaşadığını belirtmekte, \%15'lik (45 kişi) bir kesim ise olumlu ya da olumsuz bir düşünce belirtmemektedir. Verilere bakıldığında katılımcılar arasında tele-çalışmanın pozitif bir hükmünün olduğu görülmektedir.

Tablo 15. Bireysel Çatısmalar / Ailemle Daha Faz̧la Catı̧̧mam Var. Çünkü Korona Kriz̨i Nedeniyle Daba Cok Evde Vakit Geciriyorum (n=300)

\begin{tabular}{lcccc}
\hline \multicolumn{1}{c}{ Valid } & Frequency & Percent & Valid Percent & Cumulative Percent \\
\hline Tamamen katilmyorum & 34 & 11,3 & 11,3 & 11,3 \\
Katilmiyorum & 141 & 47,0 & 47,0 & 58,3 \\
Kararsizim & 33 & 11,0 & 11,0 & 69,3 \\
Katiliyorum & 64 & 21,3 & 21,3 & 90,7 \\
Tamamen katıliyorum & 28 & 9,3 & 9,3 & 100,0 \\
\hline
\end{tabular}

Katılımcıların \%30,6’s1 (92 kişi) telework sürecinde bireysel çatışma yaşadıklarını belirtmektedir. \%58,3’ü (175 kişi) bireysel olarak herhangi bir olumsuz durumla karşı karşıya kalmadıklarını ifade ederken, \%11'lik (33 kişi) bir kesim ise bu konuda kararsız kaldıklarını beyan etmektedir. Bu oranlar yorumlandığında genel sayılacak bir kesimin bireysel olarak pozitif bir süreç yaşadıkları gözlenirken, yadsınamayacak bir kesimin de bu süreçte problem yaşadığı görülmektedir. 
Tablo 16. Profesyonel Çatışmalar/ Korona Kriz̨i Nedeniyle Uzaktan Çalıştı̆̆m Ị̇in Daha Cok Profesyonel Catismalarm $\operatorname{Var}(n=300)$

\begin{tabular}{lcccc}
\hline \multicolumn{1}{c}{ Valid } & Frequency & Percent & Valid Percent & Cumulative Percent \\
\hline Tamamen katilmiyorum & 24 & 8,0 & 8,0 & 8,0 \\
Katilmiyorum & 162 & 54,0 & 54,0 & 62,0 \\
Kararsizim & 51 & 17,0 & 17,0 & 79,0 \\
Katiliyorum & 54 & 18,0 & 18,0 & 97,0 \\
Tamamen katiliyorum & 9 & 3,0 & 3,0 & 100,0 \\
\hline
\end{tabular}

Katılıcıların \%21’i (63 kişi) profesyonel çatışmalar yaşayarak yönetici ya da iş arkadaşları ile anlaşmazılık yaşadığını aktarmaktadır. Bunun yanı sıra \%62'lik (186 kişi) bir kesimin sorunsuz iş akışını profesyonel olarak devam ettirdiği görülmektedir. Karasız kalanların oranı ise \%17'dir (51 kişi).

Tablo 17. Korona Krizi Nedeniyle Uzaktan Calısma Sirasında Aile Üyeleri Tarafindan Sık Sık Rahatsız Edilirim $(n=300)$

\begin{tabular}{lcccc}
\hline \multicolumn{1}{c}{ Valid } & Frequency & Percent & Valid Percent & Cumulative Percent \\
\hline Tamamen katilmiyorum & 30 & 10,0 & 10,0 & 10,0 \\
Katılmiyorum & 163 & 54,3 & 54,3 & 64,3 \\
Kararsizım & 30 & 10,0 & 10,0 & 74,3 \\
Katilyorum & 59 & 19,7 & 19,7 & 94,0 \\
Tamamen katiliyorum & 18 & 6,0 & 6,0 & 100,0 \\
\hline
\end{tabular}

Katılımcıların \%25,7'si (67 kişi) bireysel çatışma yaşadıklarını bir kez daha beyan etmektedir. \%10’luk (30 kişi) bir grup herhangi bir fikir beyan etmezken, \%64,33'lük (193 kişi) makro bir kesim problemsiz bir uzaktan çalışma süreci geçirdiklerini ifade etmektedir.

Tablo 18. Korona Kriz̨i Nedeniyle Tele Calıșma Sırasında Farkh İletişim Araçlarmı Kullanmayı Zor Buluyorum $(n=300)$

\begin{tabular}{lcccc}
\hline \multicolumn{1}{c}{ Valid } & Frequency & Percent & Valid Percent & Cumulative Percent \\
\hline Tamamen katilmiyorum & 89 & 29,7 & 29,7 & 29,7 \\
Katilmiyorum & 157 & 52,3 & 52,3 & 82,0 \\
Kararsizım & 25 & 8,3 & 8,3 & 90,3 \\
Katilyorum & 22 & 7,3 & 7,3 & 97,7 \\
Tamamen katiliyorum & 7 & 2,3 & 2,3 & 100,0 \\
\hline
\end{tabular}

Katılımcıların \%9,6's1 (29 kişi) telework çalışma sürecinde gerekli olan iletişim araçlarını kullanmakta zorluk çekerken, \%8,33’ük (25 kişi) katılımcı oranı herhangi bir düşünce belirtmemektedir. Çağrı merkezi çalışanlarının \%82'si (246 kişi) ise iletişim araçlarının kullanımı kolay bularak herhangi bir aksaklık yaşamadıklarını ifade etmektedir. 300 kişilik bir anket verisinde 246 kişinin iletişim araçları kullanımındaki olumlu düşünceleri dijitalleşmenin pozitif etkilerinden biri olarak gösterilebilir.

Tablo 19. Korona Krizi Nedeniyle Tele Çalş̧a Düzeninde İsverenim Veya Yöneticim Tarafindan İyi Yönlendirildiüzimi Hissediyorum $(n=300)$

\begin{tabular}{lcccc}
\hline \multicolumn{1}{c}{ Valid } & Frequency & Percent & Valid Percent & Cumulative Percent \\
\hline Tamamen katilmiyorum & 11 & 3,7 & 3,7 & 3,7 \\
Katılmiyorum & 39 & 13,0 & 13,0 & 16,7 \\
Kararsizım & 89 & 29,7 & 29,7 & 46,3 \\
Katilyyorum & 145 & 48,3 & 48,3 & 94,7 \\
Tamamen katiliyorum & 16 & 5,3 & 5,3 & 100,0 \\
\hline
\end{tabular}

Katılımcıların \%53,6's1 (161 kişi) telework çalışma sisteminde yöneticisi tarafindan iyi bir şekilde yönlendirildiğini hissetmektedir. \%29,7’si (89 kişi) herhangi bir yorumda bulunmazken, \%16,7'lik (50 kişi) bir bölüm yöneticisi tarafından iyi bir yönlendirmeye sahip olmadığını düşünmektedir.

Tablo 20. İsverenimi Uzun Süreli Tele Calısmaya Katılmama İzin Vermeye İkna Etmek Zordu (n=300)

\begin{tabular}{lcccc}
\hline \multicolumn{1}{c}{ Valid } & Frequency & Percent & Valid Percent & Cumulative Percent \\
\hline Tamamen katilmiyorum & 42 & 14,0 & 14,0 & 14,0 \\
Katılmiyorum & 154 & 51,3 & 51,3 & 65,3 \\
Kararsizim & 71 & 23,7 & 23,7 & 89,0 \\
Katiliyorum & 24 & 8,0 & 8,0 & 97,0 \\
Tamamen katiliyorum & 9 & 3,0 & 3,0 & 100,0 \\
\hline
\end{tabular}


Katılımcıların \%11'i (33 kişi) işvereni tele çalışmaya ikna etmenin zor olduğunu belirtmektedir. \%23,7'si (71 kişi) bu soruya yanıt vermede çekimser kalmıştır. \%65,3'lük (196 kişi) büyük bir katılımc1 grubunun işveren ya da yöneticilerini telework sistemine geçişte ikna etmelerinin zor olmadığını aktarmaktadır. Bu verilere istinaden şirketlerin COVID-19 krizi nedeniyle tele çalışma sistemine hızlı adapte olduğu söylenebilmektedir.

Tablo 21. Korona Kriz̨i Nedeniyle İsimi Tele Çalşsmalarda Daba Verimli Yapabilirim (n=300)

\begin{tabular}{lcccc}
\hline \multicolumn{1}{c}{ Valid } & Frequency & Percent & Valid Percent & Cumulative Percent \\
\hline Tamamen katilmiyorum & 13 & 4,3 & 4,3 & 4,3 \\
Katilmiyorum & 26 & 8,7 & 8,7 & 13,0 \\
Kararsizim & 60 & 20,0 & 20,0 & 33,0 \\
Katiliyorum & 156 & 52,0 & 52,0 & 85,0 \\
Tamamen katiliyorum & 45 & 15,0 & 15,0 & 100,0 \\
\hline
\end{tabular}

Katılımcıların \%67’si (201 kişi) bu süreçte çalışma verimliliğinin daha yüksek olacağını aktarmaktadır. \%20'lik (60 kişi) kesim bu soruyu yanıtlamakta kararsız kalırken, \%13'lük (39 kişi) bir katılımcı oranı ise çalışma verimliliğinin düştüğünü belirtmektedir.

Tablo 22. Korona Kriz̨i Nedeniyle Tele Çalısma Sürecinde İsverenime Daba Bağll Hissediyorum (n=300)

\begin{tabular}{lcccc}
\hline \multicolumn{1}{c}{ Valid } & Frequency & Percent & Valid Percent & Cumulative Percent \\
\hline Tamamen katilmiyorum & 14 & 4,7 & 4,7 & 4,7 \\
Katılmiyorum & 51 & 17,0 & 17,0 & 21,7 \\
Kararsizım & 104 & 34,7 & 34,7 & 56,3 \\
Katiliyorum & 115 & 38,3 & 38,3 & 94,7 \\
Tamamen katiliyorum & 16 & 5,3 & 5,3 & 100,0 \\
\hline
\end{tabular}

Katılımcıların \%21,7'si (65 kişi) telework çalışma sisteminde yöneticilerine bağlllıklarının düştüğünü ifade etmektedir. Kararsız kalanların oranı ise \%34,7 (104 kişi) dir. \%43,6’lık (131 kişi) veri ile katılımcıların çoğunluğu yöneticilerine bağlılık hislerinin daha da arttığını belirtmektedir.

Tablo 23. Korona Kriz̨i Nedeniyle Tele Çalssma Sürecinde Daba İyi Bir İş Yassam Dengesi Yaşyorum (n=300)

\begin{tabular}{lcccc}
\hline \multicolumn{1}{c}{ Valid } & Frequency & Percent & Valid Percent & Cumulative Percent \\
\hline Tamamen katilmiyorum & 16 & 5,3 & 5,3 & 5,3 \\
Katılmiyorum & 48 & 16,0 & 16,0 & 21,3 \\
Kararsizım & 56 & 18,7 & 18,7 & 40,0 \\
Katiliyorum & 122 & 40,7 & 40,7 & 80,7 \\
Tamamen katiliyorum & 58 & 19,3 & 19,3 & 100,0 \\
\hline
\end{tabular}

Katılımcıların \%60'ı (180 kişi) telework sürecinde iş-yaşam balansının olumlu yönde ilerlediğini belirtirken, katılımcıların \%18,7'si (56 kişi) hiçbir fikir beyan etmemiştir. \%21,3’lük (64 kişi) bölüme bakıldığında ise iş-yaşam balansında olumsuz bir süreç yaşadığı görülmektedir. Bu grafik ş̧ı̆̆ında bireylerin çalışma düzenlerindeki farklılaşmaların toplumsal yaşantılarına pozitif endeksinin gerçekleştiği söylenebilir.

Tablo 24. Korona Kriz̨i Vesilesiyle Tele Calışma Düzeni Sayesinde Cahlsma Arkadaşlarmla Daba Güclü Bir Bă̆ Olduğunu Hissediyorum $(n=300)$

\begin{tabular}{lcccc}
\hline \multicolumn{1}{c}{ Valid } & Frequency & Percent & Valid Percent & Cumulative Percent \\
\hline Tamamen katilmiyorum & 19 & 6,3 & 6,3 & 6,3 \\
Katılmiyorum & 91 & 30,3 & 30,3 & 36,7 \\
Kararsizim & 109 & 36,3 & 36,3 & 73,0 \\
Katıliyorum & 66 & 22,0 & 22,0 & 95,0 \\
Tamamen katiliyorum & 15 & 5,0 & 5,0 & 100,0 \\
\hline
\end{tabular}

Katılımcıların \%27’si (81 kişi) çalışma arkadaşlarıyla aralarındaki bağın bu süreçte güçlendiğini düşünmektedir. \%36,3’lük (109 kişi) bir katılımcı grubu iş arkadaşlarılyla aralarındaki bağ konusunda çekimser kalmaktadır. \%36,6'lık (110 kişi) büyük bir kesim ise çalışma arkadaşlarıyla aralarındaki bağın düşüşe geçtiğini belirtmektedir. Sonuç olarak iş ortamından uzak kalmanın vermiş olduğu etki ile iş ortaklarının birbiriyle olan bağlantılarının zayıfladığı söylenebilir. 
Tablo 25. Korona Krizi Nedeniyle Tele Callsma Sistemi İle İsle İlgili Daba Az Stres Yassyorum (n=300)

\begin{tabular}{lcccc}
\hline \multicolumn{1}{c}{ Valid } & Frequency & Percent & Valid Percent & Cumulative Percent \\
\hline Tamamen katilmiyorum & 14 & 4,7 & 4,7 & 4,7 \\
Katılmiyorum & 39 & 13,0 & 13,0 & 17,7 \\
Kararsizim & 43 & 14,3 & 14,3 & 32,0 \\
Katiliyorum & 158 & 52,7 & 52,7 & 84,7 \\
Tamamen katiliyorum & 46 & 15,3 & 15,3 & 100,0 \\
\hline
\end{tabular}

Katıllımcıların \%17,7'si (53 kişi) telework çalışma sisteminde işle ilgili stres düzeyinin düşmediğini iletirken, \%14,3’ü (43 kişi) stres yönetimi ile ilgili herhangi bir beyanda bulunmamaktadır. \%68'lik (204 kişi) makro bir kesim telework çalışma sisteminin stres yönetiminde olumlu sonuç verdiğini ve işle ilgili daha az stres yaşadıklarını belirtmektedir. Bu bilgiler ışı̆̆ında telework çalışma sistemiyle bireylerin stres skalasının düşüşe geçtiği ve iş verimliliklerinin arttı̆̆ı söylenebilir.

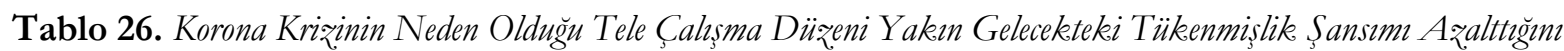
Düs̈̈n̈ïyorum $(n=300)$

\begin{tabular}{lcccc}
\hline \multicolumn{1}{c}{ Valid } & Frequency & Percent & Valid Percent & Cumulative Percent \\
\hline Tamamen katilmiyorum & 19 & 6,3 & 6,3 & 6,3 \\
Katılmiyorum & 38 & 12,7 & 12,7 & 19,0 \\
Kararsizım & 69 & 23,0 & 23,0 & 42,0 \\
Katıliyorum & 136 & 45,3 & 45,3 & 87,3 \\
Tamamen katiliyorum & 38 & 12,7 & 12,7 & 100,0 \\
\hline
\end{tabular}

\%58'lik (174 kişi) bir katıllımcı grubu tele-çalışmanın süregelen iş koşulları içerisinde tükenmişlik ihtimalini aza indirgediğini düşünmektedir. Kararsız olan grup \%23'lük (69 kişi) bir kesimi temsil ederken, \%19’luk (57 kişi) bir katılımcı grubu ise tükenmişlik ihtimalinin olumsuz yönde etkilendiğini ifade etmektedir.

Tablo 27. Korona Kriz̧i Nedeniyle Olusturulmus Tele Çalssma Düzeni Sayesinde Isste Daha İyi Konsantrasyon Deneyimi Yastyorum (n=300)

\begin{tabular}{lcccc}
\hline \multicolumn{1}{c}{ Valid } & Frequency & Percent & Valid Percent & Cumulative Percent \\
\hline Tamamen katilmiyorum & 9 & 3,0 & 3,0 & 3,0 \\
Katılmiyorum & 48 & 16,0 & 16,0 & 19,0 \\
Kararsizım & 51 & 17,0 & 17,0 & 36,0 \\
Katıliyorum & 152 & 50,7 & 50,7 & 86,7 \\
Tamamen katiliyorum & 40 & 13,3 & 13,3 & 100,0 \\
\hline
\end{tabular}

Katılımcıların \%17'si (51 kişi) iş konsantrasyon düzeyi konusunda çekimser kalırken, \%19’u (57 kişi) telework düzeninin iş sürecinde konsantrasyon seviyesinde negatif bir etki oluşturduğunu aktarmaktadır. Katılımcıların \%64'lük (192 kişi) önemli bir çoğunluğu telework çalışma düzeninde üst düzeyde konsantrasyon deneyimi yaşadıklarını beyan etmektedir. Bu oranlamayla odak-konsantrasyon düzeyinin tele-çalışma ile birlikte ivme kazandığı belirtilebilir.

\begin{tabular}{|c|c|c|c|c|}
\hline \multicolumn{5}{|c|}{ Tablo 28. Mevcut Korona Krizi Nedeniyle Artık Tele Çalısmaya Daha Olumlu Bakiyorum (n=300) } \\
\hline Valid & Frequency & Percent & Valid Percent & Cumulative Percent \\
\hline Tamamen katılmiyorum & 12 & $\overline{4,0}$ & 4,0 & 4,0 \\
\hline Katılmiyorum & 22 & 7,3 & 7,3 & 11,3 \\
\hline Kararsızım & 46 & 15,3 & 15,3 & 26,7 \\
\hline Kattlyyorum & 144 & 48,0 & 48,0 & 74,7 \\
\hline Tamamen katiliyorum & 76 & 25,3 & 25,3 & 100,0 \\
\hline
\end{tabular}

Katılımcıların \%11,33’ü (34 kişi) tele-çalışma düzenine olumsuz bir bakış açısına sahipken, \%15,33’ü (46 kişi) telework sistemi ile ilgili herhangi bir görüş beyan etmemektedir. Makro bir kesim olarak \%73,33’lük (220 kişi) bir katılımcı grubu telework sistemine daha olumlu bir bakış açısı gözetmektedir. 
Sonuç olarak COVID-19 krizi vasıtasıyla iş aksındaki değiş̧imin çağrı merkezi işgörenleri tarafinca olumlu karşılandığı belirtilebilir.

Tablo 29. Mevcut Korona Krizi Nedeniyle Gelecekte Daba Fąla Tele Çalşsa Yapabileceğimi Umuyorum (n=300)

\begin{tabular}{lcccc}
\hline \multicolumn{1}{c}{ Valid } & Frequency & Percent & Valid Percent & Cumulative Percent \\
\hline Tamamen katilmiyorum & 15 & 5,0 & 5,0 & 5,0 \\
Katılmiyorum & 19 & 6,3 & 6,3 & 11,3 \\
Kararsizim & 46 & 15,3 & 15,3 & 26,7 \\
Katıliyorum & 154 & 51,3 & 51,3 & 78,0 \\
Tamamen katiliyorum & 66 & 22,0 & 22,0 & 100,0 \\
\hline
\end{tabular}

Katılımcıların \%73,33’ü (220 kişi) büyük bir çoğunluk sağlayarak ilerleyen süreçte daha fazla telework çalışma sistemiyle iş yapabileceklerini umut etmektedir. \%15,33’ü (46 kişi) bu soruya kayıtsız kalırken, \%11,33'lük (34 kişi) mikro bir kesim ise yakın gelecekte telework sisteminde iş yürütmeyi istemediklerini belirtmektedir. Elde edilen makro sonuca göre çağrı merkezi (25-30) işgörenlerinin telework sisteminde sürekliliğin devam etmesini istedikleri bilgisine ulaşabilir.

Tablo 30. Mevcut Korona Krizi Nedeniyle Gelecekte Ülkemizde Cok Daba Fazla Tele Calssma Yapulacaktır ( $=300$ )

\begin{tabular}{lcccc}
\hline \multicolumn{1}{c}{ Valid } & Frequency & Percent & Valid Percent & Cumulative Percent \\
\hline Tamamen katilmyorum & 5 & 1,7 & 1,7 & 1,7 \\
Katılmiyorum & 8 & 2,7 & 2,7 & 4,3 \\
Kararsizim & 67 & 22,3 & 22,3 & 26,7 \\
Kattliyorum & 153 & 51,0 & 51,0 & 77,7 \\
Tamamen katiliyorum & 67 & 22,3 & 22,3 & 100,0 \\
\hline
\end{tabular}

Gelecekte ülkemizde daha çok tele-çalışmanın gerçekleştirilmesine dair kararsız kalan kesim \%22,33 (67 kişi) tür. \%4,4’lük (13 kişi) küçük bir grup telework sisteminin süreğenliğini istemezken, \%73,33’lük (220 kişi) kayda değer bir katıllımcı grubu gelecekte de telework çalışma sisteminin devamlılığını istemektedir. Bu istatistiğe göre bireylerin telework çalışma sisteminin iş yaşantısına yerleşmesine sıcak baktıkları anlaşılabilir.

Tablo 31. Mevcut Korona Krizi Nedeniyle Artık Dijital Toplantılara Daba Olumlu Bakıyorum (n=300)

\begin{tabular}{lcccc}
\hline \multicolumn{1}{c}{ Valid } & Frequency & Percent & Valid Percent & Cumulative Percent \\
\hline Tamamen katilmiyorum & 8 & 2,7 & 2,7 & 2,7 \\
Katılmiyorum & 17 & 5,7 & 5,7 & 8,3 \\
Kararsizim & 41 & 13,7 & 13,7 & 22,0 \\
Katiliyorum & 145 & 48,3 & 48,3 & 70,3 \\
Tamamen katiliyorum & 89 & 29,7 & 29,7 & 100,0 \\
\hline
\end{tabular}

Katıllımciların \%8,4’ü (25 kişi) COVID-19 krizinin beraberinde getirdiği dijital toplantılara sıcak bakmadığını, \%13,7'sinin (41 kişi) ise bu konuya dair herhangi bir fikrinin olmadığını söylemek mümkündür. \%78'lik (234 kişi) ciddi bir çoğunluğun dijital toplantılara ve dijitalleşme sürecine çok olumlu baktı̆̆ görülmektedir. Bu veriler, dijitalleşmenin hayatımız üzerinde önemli bir yer edineceğinin göstergesi olabilir

Tablo 32. Mevcut Korona Križi Nedeniyle Gelecekte Daba Fazla Profesyonel Toplantımin Dijital Olarak Yapılacağın Umuyorum $(n=300)$

\begin{tabular}{lcccc}
\hline \multicolumn{1}{c}{ Valid } & Frequency & Percent & Valid Percent & Cumulative Percent \\
\hline Tamamen katilmiyorum & 8 & 2,7 & 2,7 & 2,7 \\
Katılmiyorum & 17 & 5,7 & 5,7 & 8,3 \\
Kararsizim & 42 & 14,0 & 14,0 & 22,3 \\
Katıliyorum & 155 & 51,7 & 51,7 & 74,0 \\
Tamamen katiliyorum & 78 & 26,0 & 26,0 & 100,0 \\
\hline
\end{tabular}

Katılımcıların \%77,7'si (233 kişi) büyük bir oran ile yakın gelecekte profesyonel iş toplantılarının dijital olarak sürdürülmesini umut etmektedir. \%14'lük (42 kişi) bir kesim bu konuda kararsız kalırken, $\% 8$,'lük (25 kişi) bir katılımcı grubu ise profesyonel iş toplantılarının dijital olarak sürdürülmesini 
istememektedir. Sonuç olarak çağıı merkezi (25-30) işgörenlerinin profesyonel iş süreçlerini dijital ortamda yürütmek istedikleri söylenebilir.

Tablo 33. Mevcut Korona Krizi Nedeniyle Gelecekte Ülkemizde Daba Birçok Dijital Toplantı Düzenlenecek (n=300)

\begin{tabular}{lcccc}
\hline \multicolumn{1}{c}{ Valid } & Frequency & Percent & Valid Percent & Cumulative Percent \\
\hline Tamamen katilmiyorum & 6 & 2,0 & 2,0 & 2,0 \\
Katılmiyorum & 7 & 2,3 & 2,3 & 4,3 \\
Kararsizim & 51 & 17,0 & 17,0 & 21,3 \\
Katiliyorum & 163 & 54,3 & 54,3 & 75,7 \\
Tamamen katiliyorum & 73 & 24,3 & 24,3 & 100,0 \\
\hline
\end{tabular}

Ülkemizde telework çalışma sistemi kapsamında dijital toplantıların gelecekte de düzenlenmesi hususunda kararsız kalan kesim \%4,33'tür (13 kişi). \%17'si (51 kişi) gelecekteki dijitalleşme sürecine olumlu bakmazken, \%78,6'lık (236 kişi) makro katılımcı grubu ülkemizde telework çalışma sisteminin etkisiyle dijital toplantıların düzenleneceğini ve devamlılığın geleceğini düşünmektedir.

\section{Tartışma, Sonuç ve Öneriler}

Bilgi ve iletişim teknolojileriyle süregelen yeni normal çalışma düzeni telework çalışma sistemi, COVID-19 krizi ile birlikte oldukça rağbet görmektedir. Örgütlenme, işveren ve işgörenler etrafinda yoğunlaşan telework çalışma düzeni her geçen gün daha da gündemde yerini almaktadır. COVID-19 krizi toplumsal yaşam ve çalışma hayatı üzerinde değişimlere neden olarak pek çok kurumun farklı faaliyet alanları oluşturmasına ve yeni uygulamaları iş hayatına adapte etmesine sebebiyet vermektedir.

Telework çalışma sisteminin işverenler ve işgörenler üzerinde iş-yaşam balansı, stres yönetimi, esneklik, dönüşümlü çalışma düzeni, konsantrasyon, verimlilik gibi birçok hususta önemli etki alanına sahip olduğu bilinmektedir. Ancak, şimdiye kadar yapılan araştırmalara göre işgörenlerin maruz kaldığ1 problemlerin temel olarak, tele-çalışmanın normal çalışma biçiminin yerine geçtiğinde değil, normal çalışmaya eklendiğinde gözlemlendiğini ortaya koymaktadır. Tele çalışma sistemi işgörenler tarafında belirli firsat ve zorlukları beraberinde getirirken, yönetim ekibi ve şirket danışanları ile yapılan toplantı, iş alışverişi gibi konularda iletişim mecraları vasıtasıyla gerçekleştirilen sosyal diyaloglarda daha aktif rol alması sağlanmaktadır.

COVID-19 krizi ile yaşamımızda tamamıyla yer edinen telework sistemi yenilikleri ve farklı girişimleri beraberinde getirmektedir. Organizasyonel sürdürülebilirliğin sağlanması hususunda uygulama ve politikaların geliştirilmesi işveren ve işgören iş düzenlerinde yeni yapılanmalara gidilmesine olanak tanımaktadır. Bu evrede ülkemizin yeni normali haline gelen "telework çalışma sistemi” araştırmamız ekseninde işgören algıları ile saptanmaya çalışılmış dijitalleşmenin imkânları ile buluştuğunda ne yöne evrileceği gözlemlenmek istenmiştir. Elde edilen verilere göre telework sistemi en çok iş-yaşam dengesi, iş stresinin indirgenmesi, verimlilik artışı, tükenmişlik ihtimalinin düşürülmesi üzerinde olumlu sonuç verirken terfi olanaklarında, kariyer ilerlemelerinde ve çalışma arkadaşları ile olan ilişkilerde belirli olumsuz bulgulara rastlandığı gözlemlenmektedir. Baert ve çalışma arkadaşlarının (2020) bahar döneminde yapmış olduğu araştırma sonucunda elde edilen bulgulara göre telework çalışma sisteminin artan verimlilik ve daha iyi iş-yaşam dengesi gibi bazı olumlu özellikleri varken kariyer ilerleme firsatları ve çalışma ilişkileri üzerinde bazı olumsuz etkilerinin bulunmuş olması, çalışmamızın benzer etkiler sunduğunu ve işgören algılarının ortak olduğu yargısına varılabileceğini göstermektedir.

Telework çalışma sistemleri, hem kurum ve kuruluşların iktisadi hareketliliğini dinamik tutmakta hem işgörenlerin sıhhat ve emniyetini güven altına almaktadır. Bunun bir sonucu olarak araştırmada çağrı merkezi işverenlerin pandemi sürecince çalışma sistemini yeni yapıya uyumlandırarak çalışanlarını hızlı adapte ettiği ve iş yönetimini iyi gerçekleştirdiği işgörenler tarafından aktarılmaktadır. Ayrıca katılımcıların işveren yahut yöneticilerine bağlllık yüzdesinin de yüksek oranda olduğu dikkat çekmektedir. Telework bir bakıma işveren için örgütsel maliyeti indirgemeyi hedeflese de iş- yaşam balansını tehsil etmek ve iş baskısını düşürmek için daha çok uygulama alanı bulmaktadır. Bu açıdan bakıldığında varılan bulgular, işgörenlerin aile ilişkilerini sağlamlaştırmakta, zaman idaresini optimize etmekte, ev-aile sorumluluklarını yerine getirmeye olanak tanıyarak iş- yaşam görevlerini dengeleme esnekliği sunmaktadır. COVID-19 krizi vasıtasıyla oluşan iş düzeni ve iletişim araçları koalisyonu sonucunda işgörenler farklı deneyim düzeyleri yaşamaya başlamaktadır. Çağrı merkezi işgörenlerinden alınan verilere göre; dijital toplantı ve müzakerelerin olumlu etkilerinin olduğu, yakın gelecekte de dijitalleşmenin verimlerinden faydalanmak 
istedikleri belirtilmektedir. Buna istinaden gelecekte telework çalışma sistemi ve dijitalleşmenin esas kaynak olarak görülmek istendiği ve iş verimliliğine üst seviyede yarar sağladığı kanısına varmak mümkündür.

Dönüşüme hazır olan bireyler üzerinden değerlendirildiğinde, COVID-19 kriz süreci atlatıldıktan sonra da işgören ve işverenlerin harekete geçme konusunda değişim, gelişim ve yeniliklere açık olacağı ve dijitalleşme anlamında yeni girişimlerde bulunacağı ön görülmektedir. İş alanları ve çalışma prensipleri sektörel bazda devinime uğrayacak ve elde edilen deneyimler neticesinde dijital rekabetçilik ortaya çıkacaktır. Dijital dönüşüm sürecinde araştırma ve geliştirme faaliyetlerinin hız kazanması, özellikle Covid19 sonrasinda teknoloji temelli rekabet avantaji sağlayacak ürün, hizmet ve iş modellerini ortaya çıkarabilecek girişimlere odaklanmalarını teşvik edecektir. Dünya düzenin dijitalleşme ve teknoloji güçleri üzerinde olacağı ve çalışma biçiminin buna göre şekil alacağı beklenmektedir.

Gelecekteki araştırmalarda oluşabilecek boşluğu doldurmak, telework çalışma düzeni ile ilgili yaşanabilecek firsat ya da güçlükleri ortaya koymak, işgören algılarını net algılayabilmek ve aktarabilmek, bu sistemde oluşabilecek sorunlara çözüm üretebilmek ve COVID-19 sürecinde değişim ve dönüşümleri deneyimleyen bireylerin fikirleri değerlendirebilmek amaciyla yürütülen bu çalışma, ilerleyen sürelerde araştırılacak yapıcı çalışmaların geliştirilmesi hususunda literatüre katkı sağlayacaktır.

\section{Etik Beyan}

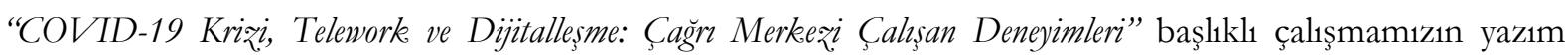
sürecinde bilimsel kurallara, etik ve alıntı kurallarına uyulmuş; toplanan veriler üzerinde herhangi bir tahrifat yapılmamış ve bu çalışma herhangi başka bir akademik yayın ortamına değerlendirme için gönderilmemiştir. Çalışma, Sakarya Üniversitesi Sosyal ve Beşeri Bilimler Etik Kurulu Başkanlığının 03.02.2021 tarihli ve 31 sayılı toplantısında alınan 20 no'lu karar ile uygun görülmüş ve çalışmanın gerçekleştirilmesinde etik sakınca bulunmadığına kanaat getirilmiştir.

\section{Kaynakça}

Aksoy, B. (2012). Bilgi teknolojileri ve yeni çalışma ilişkileri. Ege Akademik Bakııs, 12(3), 401-414. doi:10.21121/eab.2012319527

Alpago, D., ve Alpago, Ö. (2020). Koronavirüs salgınının sosyoekonomik sonuçları. IBAD Sosyal Bilimler Dergisi(8), 99-114. doi:https://doi.org/10.21733/ibad.716444

Baert, S., Lippens, L., Moens, E., Sterkens, P. ve Weytjens, J. (2020, May1s). The COVID-19 crisis and telework: A research survey on experiences, expectations and hopes. IZA - Institute of Labor Economics, 2-37. Erişim adresi: http://ftp.iza.org/dp13229.pdf

Bouziri, H., Smith, D., Descatha, A., Dab, W. ve Jean, K. (2020). Working from home in the time of COVID-19: how to best preserve occupational health? Occupational and Environmental Medicine, 77(7). doi:http://dx.doi.org/10.1136/oemed-2020-106599

Bozkurt, V. (2020, Temmuz). Pandemi döneminde çalş̧ma: Ekonomik kaygılar, dijitalleşme ve verimlilik. İstanbul Üniversitesi, 116-136. doi:10.26650/B/SS46.2020.005.08

Brown, J. ve Duguid, P. (2001). Enformasyonun sosyal yaşamı (Çev: İ. Bingöl) İstanbul: Türk Henkel Dergisi Yayınları.

Burch, S. (1991). Teleworking: A Strategic Guide for Management. London: Kogan Page.

Dingel, J. ve Neiman, B. (2020). How Many Jobs Can be Done at Home? University of Chicago, Booth School of Business NBER, and CEPR, 2-14. doi:10.3386/w26948

Dockery, A. M. ve Sherry, B. (2020). Working from Home in the COVID-19 Lockdown. Bankwest Curtin Economics Centre Research Brief COVID-19, 5, 1-5. Erişim adresi: https://bcec.edu.au/assets/2020/05/BCEC-COVID19Brief-4_Working-from-home.pdf

Erdut, T. (1998). Yeni teknolojilerin iş iliskkileri üzerindeki etkisi. İzmir: Tuhis Yayınları.

Eröz, S. S. (2020). Siber aylaklık. İçinde M. Avc1, \& E. Kara (Edt.). Örgütsel davranı̧̧ üz̨erine güncel çalışmalar (1. Baskı). İstanbul: Hiper Yayın.

Ersöz, B. ve Özmen, M. (2020, Ekim 17). Dijitalleşme ve bilişim teknolojilerinin çalışanlar üzerindeki etkileri. Bilişim Teknolojileri Online Dergisi, 11(42), 171-179. doi:10.5824/ajite.2020.03.007.x

Fadinger, H. ve Schymik, J. (2020, Nisan 20). The effects of working from home on Covid-19 infections and production a macroeconomic analysis for Germany. University of Bonn andUniversity of Mannbeim, Germany, 1-20. Erişim adresi: https://www.wiwi.uni-bonn.de/bgsepapers/boncrc/CRCTR224_2020_167.pdf

Görmüş, A. (2020). Kovid-19 pandemisi döneminde sosyal mesafeli çalşsma biçimi: Tele-çallşsma. Turkish Studies,

15(4), 481-496. doi:http://dx.doi.org/10.7827/TurkishStudies.44261

Greenhaus, J. ve Beutell, N. (1985, Ocak). Source of conflict between work and family roles. The Academy of Management Review, 76-88. doi:10.2307/258214

İnceacar, T. (2019, Haziran). Tele çalssma ve ortaya ģıkan sorunlarm çalssanlar üzerindeki etkisi. 3. Uluslararası EMI Girişimcilik ve Sosyal Bilimler Kongresinde sunulan bildiri, Gaziantep Üniversitesi- EMISSC. Lefkoşa. 
Lim, V. K. (2002, Ağustos). The IT way of loafing on the job: Cyberloafing, neutralizing and organizational justice. Journal of Organizational Behavior, 23 (5) 675-694. doi:10.1002/job.161

Meşhur, H. F. (2007, Şubat). Geleceğin çalışma biçimi tele çalışmaya iliş̧kin yaklaşımlar. Akademik Bilişim’07- IX. Akademik Bilişim Konferansında sunulan bildiri, Dumlupınar Üniversitesi, Kütahya.

Meşhur, H. F. (2010). Organizasyonların tele çalışmaya ilişkin tutumlarına yönelik bir araştırma. Dokuz. Eylül Üniversitesi İktisadi ve İdari Bilimler Fakültesi Dergisi, 25(1), 1-24. Erişim adresi: https://dergipark.org.tr/tr/download/article-file/211054

Morganson, V., Major, D., Oborn, K., Verive, J. ve Heelan, M. (2010). Comparing telework locations and traditional work arrangements: Differences in work-life balance support, job satisfaction, and inclusion. Journal of Managerial Psychology, 25(6), 578-595. doi:https://doi.org/10.1108/02683941011056941

Ölçer, F. (2004, Haziran). Telework: 21. yüzyılın yeni çalışma biçimi. Öneri Dergisi, 6(22), 145-165. doi:https://doi.org/10.14783/maruoneri.678614

Parlak, Z. (2004). Sanayi ötesi toplum teorilerinin eleştirel bir değerlendirmesi. Kocaeli Üniversitesi Sosyal Bilimler Enstitüsü Dergisi (8), 95-125. Erişim adresi: https://dergipark.org.tr/tr/download/article-file/252026

Tan, G. (2007). Atipik $\dot{I}_{s}$ sözleşmelerinden evde çalışma ve tele çallşma (Yüksek Lisans Tezi). Başkent Üniversitesi Sosyal Bilimler Enstitüsü, Ankara.

Telli, G. (2020). Covid-19 kapsamında uzaktan çalıs̆ma ve telafi çalışmasının değerlendirilmesi. İstanbul: Aksan Hukuk. Erişim adresi: https://aksan.av.tr/tr/blog/detail/1069

Thomason, B. ve Williams, H. (2020). What will work-life balance look like after the pandemic? Harvard Business Review. Erişim adresi: https://hbr.org/2020/04/what-will-work-life-balance-look-like-after-the-pandemic.

Tokol, A. (2003). Tele Çalışma geleceğin çalışma şekli olabilir mi? İs, Güc Endüstri İlişkileri ve İnsan Kaynaklan Dergisi, 5(1). Erişim adresi: http://www.isguc.org/?p=article\&id=18\&cilt=5\&sayi=1\&yil=2003

Tutar, H. (2007). Katı Olan Her "Işs" sanallaşıyor veya işgörenin artan yalnızlı̆̆ üzerine: kuramsal bir yaklaşım. "İş, Güs” Endüstri Ilişkileri ve Insan Kaynaklar Dergisi, 9(7), 116-141. doi:10.4026/1303-2860.2007.0046.x

Türkiye Bilimler Akademisi Yayınları (2020). 2020 nisan raporu. Covid-19 küresel salgin değerlendirme raporu. TÜBA Raporları No: 34. Ankara: Türkiye Bilimler Akademisi.

Türkiye Bilimler Akademisi Yayınları (2020). 17 Nisan 2020 Raporu. COVID-19, pandemi değerlendirme raporu. TÜBA Raporları No: 34 Ankara: Türkiye Bilimler Akademisi.

Weber, M. (1985). Protestan ablâk ve kapitaliz̨min rubu (Çev: Z. Aruoba) İstanbul: Hil Yayınlar.

Yavuz, A. (1995). Esnek çalısma ve endïstri ilişkilerine etkisi. İstanbul: Filiz Kitabevi.

\section{EXTENDED ABSTRACT}

The new type of COVID-19 virus, which emerged in the last moments of 2019 and affected the whole world, first appeared in Wuhan, China, and this epidemic, which was declared as an international public health emergency by the World Health Organization, was also encountered in our country in March 2020. Many measures have been taken to prevent the spread of the disease throughout the world and within the borders of the country and a pandemic process have been introduced. In order to minimize the spread and transmission risk of the COVID-19 epidemic, social isolation and social distancing were introduced to minimize the connection of people with each other. These two rules are vital. Apart from the physical, mental or spiritual nature of the epidemic, the high rate of fatal effects has greatly changed people's living spaces and working forms. Some steps were taken towards this process; the implementation of education by switching to an online / distance education model, closing country entries and exits for a certain period of time, imposing curfews and restrictions, implementing travel restrictions, and transitioning to a flexible/rotational working system, especially for companies with suitable infrastructure. With the pandemic, some companies have gone to reduce the number of their employees or to temporarily close their workplaces in order to adapt to social distance and isolation conditions, while some companies have turned to the telework system by resorting to different ways to maintain their economic activities and protect employee health / safety.

Telework system included in the literature different concepts such as remote working, virtual office, flexible working, and information networking. Although it is the subject of controversial issue, COVID-19 appears as a new business model. Especially with the rapid development of information communication technologies and the effect of digitalization, it has been observed that telework working methods have been adopted in private sector areas and public workplaces, while the demand for telework model has increased. Depending on the development of communication technologies and information, it means that individuals can do their jobs in their own autonomous areas and change their working style without going to workplaces, and a different form of this system is explained with the concept of electronic kiosk in Alvin Toffler's book "Third Wave". The emergence of every new wave against the epidemic, the change in living standards, education levels and working conditions are an indication that this definition has begun 
to take place. This period, when the digital world and artificial intelligence technologies are integrated, provides the opportunity to change and improve the qualifications of the employees in the telework system beyond making their lives difficult. In the telework system, transforming the lifestyles of employees into digitalization and increasing their productivity and performance is of great importance in being successful in the digitalization process (Ersöz, \& Özmen, 2020).

Telework working systems both keep the economic mobility of institutions and organizations dynamic and ensure the health and safety of the employees. As a result of this research, it is stated by the employees that the call center employers adapt their working system to the new structure during the pandemic process, adapt their employees quickly and perform the business management well. It is also noteworthy that the percentage of participants' loyalty to their employers or managers is high. Although telework aims to reduce the organizational cost for the employer in a way, it finds more application areas to collect the work-life balance and reduce the work pressure. From this point of view, the obtained findings strengthen the family relations of employees, optimize time management, and offer flexibility to balance work-life duties by allowing them to fulfill their home-family responsibilities. As a result of the coalition of work order and communication tools created through the COVID-19 crisis, employees begin to undergo different levels of experience. According to the data received from call center employees digital meetings and negotiations have positive effects and they want to benefit from the efficiency of digitalization in the near future. Based on this, it is possible to conclude that in the future, the telework working system and digitalization are desired to be seen as the main resource and provide a high level of benefit to work efficiency.

When evaluated on individuals who are ready for transformation, it is predicted that even after the COVID-19 crisis process is over, employees and employers will be open to change, development and innovation in terms of taking action and will make new initiatives in terms of digitalization. Business areas and working principles will change on a sectoral basis and digital competitiveness will emerge as a result of the experiences gained. The acceleration of research and development activities in the digital transformation process will encourage them to focus on initiatives that can reveal products, services and business models that will provide technology-based competitive advantage, especially after Covid-19. It is expected that the world order will be on the forces of digitalization and technology and the way of working will take shape accordingly.

This study, which evaluates the ideas of individuals who experience changes and transformations in the COVID-19 process, is to fill the gap that may arise in future research, to reveal the opportunities or difficulties that may be experienced regarding the telework work order, to be able to clearly perceive and convey employee perceptions, to produce solutions to the problems that may occur in this system, and to be investigated in the future. It will contribute to the literature on the development of constructive studies. 